\title{
Pediatric low-grade glioma in the era of molecular diagnostics
}

Scott Ryall ${ }^{1,2,3}$, Uri Tabori ${ }^{1,4,5}$ and Cynthia Hawkins ${ }^{1,2,3^{*}}$

\begin{abstract}
Low grade gliomas are the most frequent brain tumors in children and encompass a spectrum of histologic entities which are currently assigned World Health Organisation grades I and II. They differ substantially from their adult counterparts in both their underlying genetic alterations and in the infrequency with which they transform to higher grade tumors. Nonetheless, children with low grade glioma are a therapeutic challenge due to the heterogeneity in their clinical behavior - in particular, those with incomplete surgical resection often suffer repeat progressions with resultant morbidity and, in some cases, mortality. The identification of up-regulation of the RAS-mitogen-activated protein kinase (RAS/MAPK) pathway as a near universal feature of these tumors has led to the development of targeted therapeutics aimed at improving responses while mitigating patient morbidity. Here, we review how molecular information can help to further define the entities which fall under the umbrella of pediatric-type low-grade glioma. In doing so we discuss the specific molecular drivers of pediatric low grade glioma and how to effectively test for them, review the newest therapeutic agents and their utility in treating this disease, and propose a risk-based stratification system that considers both clinical and molecular parameters to aid clinicians in making treatment decisions.
\end{abstract}

Keywords: Pediatric low-grade glioma, glioma, pediatric, neurofibromatosis type I, brain tumor, neuro-oncology, RAS/ MAPK pathway, molecular diagnostics, clinical trial, targeted therapy, risk stratification

\section{Introduction}

Tumors of the central nervous system (CNS) are the most frequent solid tumors in children, with approximately 5.45.6 diagnoses per $100,000[48,154,155]$. Of those diagnosed, 0.7 per 100,000 will succumb to their disease, making CNS tumors the leading cause of cancer related death in children [154, 155, 168]. Within this group, pediatric-type low-grade gliomas (pLGG) are the most frequent, accounting for approximately $30 \%$ of all childhood brain tumors $[154,155]$. pLGG are defined as World Health Organization (WHO) grade I or II malignancies and encompass a wide array of histologies that can arise throughout the neuro-axis (Fig. 1a-c) [131, 132].

\footnotetext{
* Correspondence: cynthia.hawkins@sickkids.ca

1 Arthur and Sonia Labatt Brain Tumour Research Centre, The Hospital for Sick Children, 555 University Avenue, Toronto, ON M5G 1X8, Canada

${ }^{2}$ Department of Laboratory Medicine and Pathobiology, University of Toronto, Toronto, ON, Canada

Full list of author information is available at the end of the article
}

Management of pLGG is intimately related to surgical resection, and complete resection remains the most favorable predictor of patient outcome [225]. Often, this is achievable for superficial lesions such as those arising in the cerebral hemispheres or posterior fossa, but is not always feasible for deep seated or highly infiltrative tumors [225]. In these cases, progressive residual disease has historically been treated with adjuvant chemotherapy or radiation [12, 55, 122, 124, 135, 139, 157, 183, 189]. Importantly, these treatments are associated with longterm sequelae and, particularly for radiation, increased mortality [55, 71, 118, 138, 145]. These concerns are poignant in a disease where 10-year overall survival (OS) exceeds $90 \%$. However, with progression-free survival (PFS) at approximately $50 \%$, up to half of patients will require adjuvant therapy. As such, a more robust risk stratification is required to help guide the type and intensity of therapy warranted. In the past, the degree of

(c) The Author(s). 2020 Open Access This article is licensed under a Creative Commons Attribution 4.0 International License, which permits use, sharing, adaptation, distribution and reproduction in any medium or format, as long as you give appropriate credit to the original author(s) and the source, provide a link to the Creative Commons licence, and indicate if changes were made. The images or other third party material in this article are included in the article's Creative Commons licence, unless indicated otherwise in a credit line to the material. If material is not included in the article's Creative Commons licence and your intended use is not permitted by statutory regulation or exceeds the permitted use, you will need to obtain permission directly from the copyright holder. To view a copy of this licence, visit http://creativecommons.org/licenses/by/4.0/ The Creative Commons Public Domain Dedication waiver (http://creativecommons.org/publicdomain/zero/1.0/) applies to the data made available in this article, unless otherwise stated in a credit line to the data. 

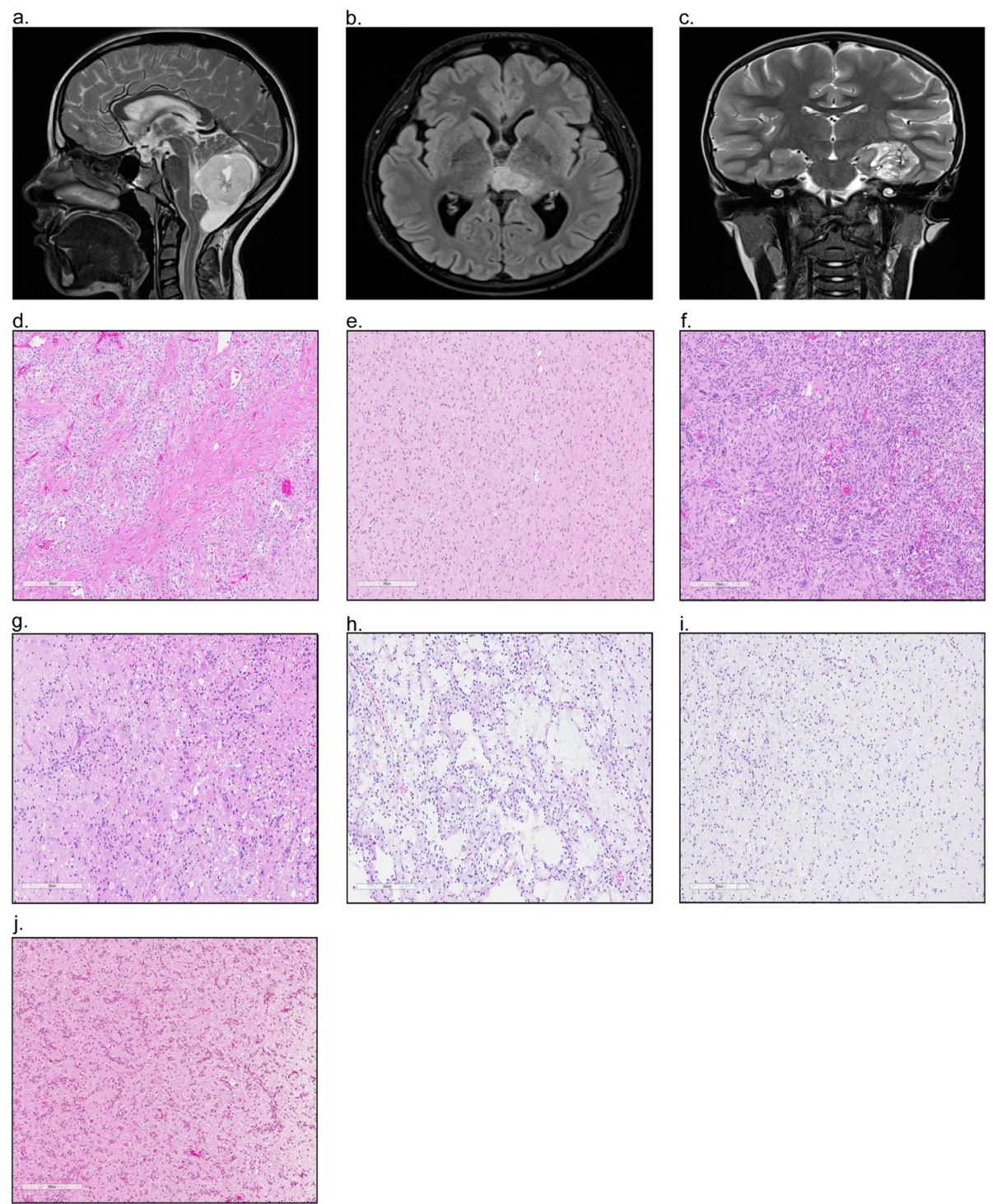

Fig. 1. Magnetic resonance imaging (MRI) depicting pediatric low-grade glioma arising in the $\mathbf{a}$. Cerebellum, b. Thalamus, and $\mathbf{c}$. Occipital Lobe. Hematoxylin and eosin (H\&E) staining highlighting the hallmark histologic features of $\mathbf{d}$. Pilocytic astrocytoma, e. Diffuse astrocytoma, $\mathbf{f}$. Pleomorphic xanthoastrocytoma, g. Ganglioglioma, h. Dysembryoplastic neuroepithelial tumour, i. Oligodendroglioma, and j. Angiocentric glioma

surgical resection, histological diagnosis and age were used to determine prognosis. However, more recently the molecular underpinnings of pLGG have emerged as a powerful tool to supplement the stratification of these tumors.

In the last decade, significant molecular data has emerged to suggest that pLGG near universally upregulate the RAS-mitogen-activated protein kinase (RAS/MAPK) pathway [34, 96, 149, 229]. This data has led to increasing use of targeted therapeutics that supplement and/or replace older cytotoxic approaches. As the era of targeted therapeutics inevitably arrives, a concise classification scheme recognizing the molecular features of pLGG is needed. Here, we will review the histological spectrum of pLGG, the molecular alterations that have been identified in these entities and how to effectively test for them, and review the newest therapeutic agents and their utility in treating this disease. We conclude with proposing a multi-faceted approach for stratifying pLGG that considers clinical, histologic and molecular parameters and aims to aid clinicians in their future treatment decisions.

\section{Morphologic Classification of pLGG}

pLGG form a heterogeneous group of neoplasms that encompass tumors of primarily glial histology, including astrocytic and/or oligodendroglial, and tumors of mixed 
neuronal-glial morphology. These tumors are considered grades I and II according to the current WHO classification where they are distinguished from high grade glioma on the basis of specific morphologic features or, in the case of diffuse glioma, based on the absence of necrosis, mitoses and microvascular proliferation [131, 132, 166, 199]. Histologic diagnoses which fall under the umbrella of pLGG and their hallmark molecular alterations are listed in Table 1; their typical histologic features are depicted in Fig. 1d-j.

In many cases the different histologic entities are readily distinguished, however cases of overlapping morphology are well documented. These include, for example, reports of histological overlap between pleomorphic xanthoastrocytoma and ganglioglioma [3, 62, 208] and between dysembryoplastic neuroepithelial tumor and oligodendroglioma [70, 114]. In addition, tumors which are classically well circumscribed, such as pilocytic astrocytoma, may possess an infiltrative component [34], leading to confusion and difficulty in grading. A precise histologic diagnosis may be particularly challenging in deep seated midline tumors, for which a small biopsy is often all that is available. Rarely do these capture the true complexity of the tumor and the classic morphologic features by which diagnoses are made are often lacking.

In addition to these difficulties, pLGG overlap morphologically with entities more commonly found in adults. This creates confusion regarding appropriate grading and treatment and is exacerbated by use of similar terminology, namely diffuse astrocytoma and oligodendroglioma. In the most recent WHO iteration, both diffuse astrocytoma and oligodendroglioma have been split based on the presence or absence of IDH1 mutations, in addition to $1 \mathrm{p} / 19 \mathrm{q}$ co-deletion for the latter. Tumors with the morphology of oligodendroglioma or diffuse astrocytoma in the pediatric age group often do not have IDH1 mutations and/or $1 \mathrm{p} / 19 \mathrm{q}$ co-deletion and are therefore considered oligodendroglioma, NEC or, of even greater concern, diffuse astrocytoma, $I D H$-wildtype. The latter raising concern for molecular glioblastoma (GBM). Both of these diagnoses may lead to conventional adult diffuse glioma treatments involving cytotoxic chemotherapy and radiation, particularly in the adolescent and young adult age group. However, in IDH1 wild-type cases, pediatric oligodendrogliomas most frequently harbor alterations in FGFR1 including TKDduplications or SNVs or BRAF p.V600E (Table 1). Recently, the entity polymorphous low-grade neuroepithelial tumor of the young (PLNTY) was described [88]. These tumors invariably possessed oligodendroglioma-like cellular components and highly infiltrative morphological features, yet boast a benign clinical course uncommonly
Table 1 Histological diagnosis and the common molecular events of WHO-recognized pLGG. RTK: receptor tyrosine kinase, SNV: single nucelotide variant

\begin{tabular}{|c|c|}
\hline Histological Diagnosis & Common Molecular Events \\
\hline \multicolumn{2}{|l|}{ Glial Tumors } \\
\hline Pilocytic Astrocytoma & $\begin{array}{l}\text { KIAA1549-BRAF (70-80\%) } \\
\text { FGFR1-TACC1 (3-5\%) } \\
\text { FGFR1 SNV (3-5\%) } \\
\text { BRAF p.V600E (3-5\%) } \\
\text { Other BRAF Fusions (2-5\%) } \\
\text { CRAF Fusions (2-5\%) } \\
\text { PTPN11 SNV (2-5\%) } \\
\text { KRAS/HRAS SNV (2-5\%) }\end{array}$ \\
\hline $\begin{array}{l}\text { Subependymal Giant Cell } \\
\text { Astrocytoma }\end{array}$ & TSC1/2 SNV (85-95\%) \\
\hline Diffuse Astrocytoma & $\begin{array}{l}\text { BRAF p.V600E (20-40\%) } \\
\text { MYBL1 alteration (5-10\%) } \\
\text { KIAA1549-BRAF (5-10\%) } \\
\text { FGFR1 SNV (2-5\%) } \\
\text { H3.3 p.K27M (2-5\%) } \\
\text { IDH1 p.R132H (2-5\%) } \\
\text { Other RTK SNV/Fusions (2-3\%) }\end{array}$ \\
\hline Pleomorphic Xanthoastrocytoma & BRAF p.V600E (80-90\%) \\
\hline Oligodendroglioma & $\begin{array}{l}\text { FGFR1-TKD duplication (10-20\%) } \\
\text { FGFR1 SNV (10-20\%) } \\
\text { BRAF p.V600E (5-10\%) } \\
\text { FGFR1-TACC1 (3-5\%) } \\
\text { IDH1 p.R132H (3-5\%) } \\
\text { 1p/19q co-deletion (3-5\%) }\end{array}$ \\
\hline \multicolumn{2}{|l|}{ Mixed Glioneuronal Tumors } \\
\hline Ganglioglioma & $\begin{array}{l}\text { BRAF p.V600E (40-50\%) } \\
\text { KIAA1549-BRAF (10-15\%) }\end{array}$ \\
\hline $\begin{array}{l}\text { Desmoplastic Infantile } \\
\text { Astrocytoma and Ganglioglioma }\end{array}$ & $\begin{array}{l}\text { BRAF pV600E/D (40-60\%) } \\
\text { FGFR1 SNV (5-10\%) } \\
\text { KIAA1549-BRAF (2-5\%) }\end{array}$ \\
\hline $\begin{array}{l}\text { Dysembryoplastic } \\
\text { Neuroepithelial Tumor }\end{array}$ & $\begin{array}{l}\text { FGFR1-TKD duplication (20-30\%) } \\
\text { FGFR1 SNV (20-30\%) } \\
\text { FGFR1-TACC1 (10-15\%) } \\
\text { Other RTK SNV/Fusions (5-10\%) } \\
\text { BRAF p.V600E (5-10) }\end{array}$ \\
\hline Papillary Glioneuronal Tumor & SLC44A1-PRKCA (80-90\%) \\
\hline $\begin{array}{l}\text { Rosette-forming Glioneuronal } \\
\text { Tumor }\end{array}$ & $\begin{array}{l}\text { PIK3CA SNV (20-30\%) } \\
\text { KIAA1549-BRAF (20-30\%) } \\
\text { FGFR1 SNV (20-30\%) }\end{array}$ \\
\hline Angiocentric Glioma & MYB (80-90\%) \\
\hline $\begin{array}{l}\text { Chordoid Glioma of Third } \\
\text { Ventricle }\end{array}$ & PRKCA SNV (80-90\%) \\
\hline $\begin{array}{l}\text { Polymorphous Low-Grade } \\
\text { Neuroepithelial tumor of the } \\
\text { Young (PLNTY) }\end{array}$ & $\begin{array}{l}\text { BRAF p.V600E (30-40\%) } \\
\text { FGFR2/3 Fusions (30-40\%) }\end{array}$ \\
\hline $\begin{array}{l}\text { Multinodular and vacuolating } \\
\text { neuronal tumor (MVNT) }\end{array}$ & $\begin{array}{l}\text { MAP2K1 SNV/Indel (50-60\%) } \\
\text { BRAF p.V600E (5-10\%) } \\
\text { Other BRAF SNV (5-10\%) } \\
\text { FGFR2 Fusions (3-5\%) }\end{array}$ \\
\hline
\end{tabular}

seen in classic $I D H$-mutant oligodendroglioma [31, 88]. These tumors do not harbor IDH1 mutations, but rather FGFR2/3 fusions (discussed further below) or BRAF p.V600E. IDH1 wild-type diffuse astrocytoma most frequently harbor BRAF p.V600E mutations, accounting for 
$\sim 40 \%$ of cases (Table 1). In addition, they sometimes contain KIAA1549-BRAF fusions, FGFR1 SNVs, or MYB or $M Y B L 1$ alterations. The latter alterations were originally described in series of pediatric diffuse astrocytomas [174, 212] and reports thus far suggest they have a benign clinical course without therapy [31]. Recently, these have been termed isomorphic diffuse glioma [223]. In these cases, misdiagnosis may result in over-treatment, leading to potentially harmful sequelae.

In recognition of the increased understanding of the molecular underpinnings of diffuse gliomas in adults, IDH1 mutation and 1p/19q deletion status were incorporated into the most recent $\mathrm{WHO}$ revision in order to improve diagnostic reproducibility and provide important prognostic information for patients [132]. A similar incorporation of molecular features into the classification of pLGG will help to more accurately identify these entities and, importantly, distinguish them from adulttype gliomas, which carry a worse prognosis and require more aggressive therapy.

\section{The Molecular Landscape of pLGG Up-regulation of the RAS/MAPK Pathway}

The last decade has produced unparalleled insights into the underlying biology of pLGG. Importantly, we now know that the majority of pLGG are driven by a single genetic event resulting in up-regulation of the RAS/ MAPK pathway [34, 96, 149, 229]. Our first indications of RAS/MAPK involvement in pLGG pathogenesis came from Neurofibromatosis Type I (NF1) patients of whom $10-15 \%$ develop low-grade glioma $[14,196,218]$. Since then, molecular profiling efforts have uncovered additional alterations within this pathway with such frequency that many have postulated that pLGG is a "one-pathway disease" [34, 96, 149, 229]. An overview of the most common RAS/MAPK pathway alterations in pLGG is shown in Fig. 2.

\section{Neurofibromatosis Type 1}

Neurofibromatosis Type I (NF1) is the most common inheritable tumor predisposition syndrome worldwide and is associated with a wide range of clinical manifestations including skin pigmentation abnormalities, learning disabilities, seizures, and vasculopathies [16, 19]. NF1 is caused by a germline mutation in the NF1 tumor suppressor gene, which encodes neurofibromin, a GTPase-activating protein that functions as a negative regulator RAS $[61,89,177] .10-15 \%$ of children with NF1 will develop a low-grade glioma within the optic pathway, with an additional 3-5\% arising outside of the optic pathway $[14,195,196$, 218]. NF1-associated gliomas usually show loss of the wild-type allele and, as a result, neurofibromin's endogenous function as a negative regulator of RAS is lost. Typically, NF1-pLGG are asymptomatic and indolent, requiring no therapeutic intervention and in some cases, regress without treatment $[87,119,126$, 127, 159]. However, in cases of clinical deterioration (most commonly vision loss), chemotherapy, and not radiation, is the first line of treatment $[87,119,126$, 127, 159, 197].

Despite their benign course, NF1-pLGG arising in younger children ( $<2$ years) and/or outside of the optic pathway are recognized as being at a higher risk of progression and/or death [59]. Historically, NF1pLGG are not biopsied due to their precarious location and the lack of clinical utility of the additional information obtained. However, a recent study uncovered that NF1-pLGG do harbor additional genetic alterations [37]. Most commonly, these were additional aberrations affecting the RAS/MAPK pathway or those involving transcriptional regulators. Furthermore, the mutational profile of NF1-pLGG was distinct from NF1-high grade glioma (HGG), which instead harbored alterations in TP53, CDKN2A and $A T R X$. Therefore, obtaining a biopsy from, at minimum, patients deemed higher risk, may prove valuable in identifying patients that require refined and/or novel treatments and distinguishing them from NF1HGG, particularly in adults.

\section{KIAA1549-BRAF}

Early studies examining copy number alterations in pilocytic astrocytoma identified focal gains at $7 \mathrm{q} 34$ which included the BRAF gene [44, 167]. Further work by Jones et. al. refined this discovery, showing that this gain was the result of a tandem duplication resulting in the formation of a novel oncogenic fusion, KIAA1549-BRAF [99]. This rearrangement resulted in the N-terminal regulatory domain of $B R A F$ being lost, leading to downstream up-regulation of the RAS/MAPK signaling pathway [99]. Five separate KIAA1549-BRAF exon-exon junctions have been described including $16 ; 9,15 ; 9,16 ; 11,18 ; 10$, and 19;9 in order of prevalence $[99,60,200,211]$, all resulting in the loss of $B R A F^{\prime}$ s regulatory domain. Subtle clinical differences between fusion variants have been noted but whether their underlying biology differs, and if additional roles of KIAA1549 exist, remain unknown $[57,78,116,181]$.

KIAA1549-BRAF is the most frequent molecular alteration in pLGG, and is significantly enriched in pilocytic astrocytoma and in tumors arising in the posterior fossa/ cerebellum (Fig. 3a, b). Despite this enrichment, additional studies have confirmed KIAA1549-BRAF in a spectrum of histologies and CNS locations [60, 90, 97, 100, 116, 171, 200, 211, 229]. In total, KIAA1549-BRAF accounts for $30-40 \%$ of pLGG at the population level 


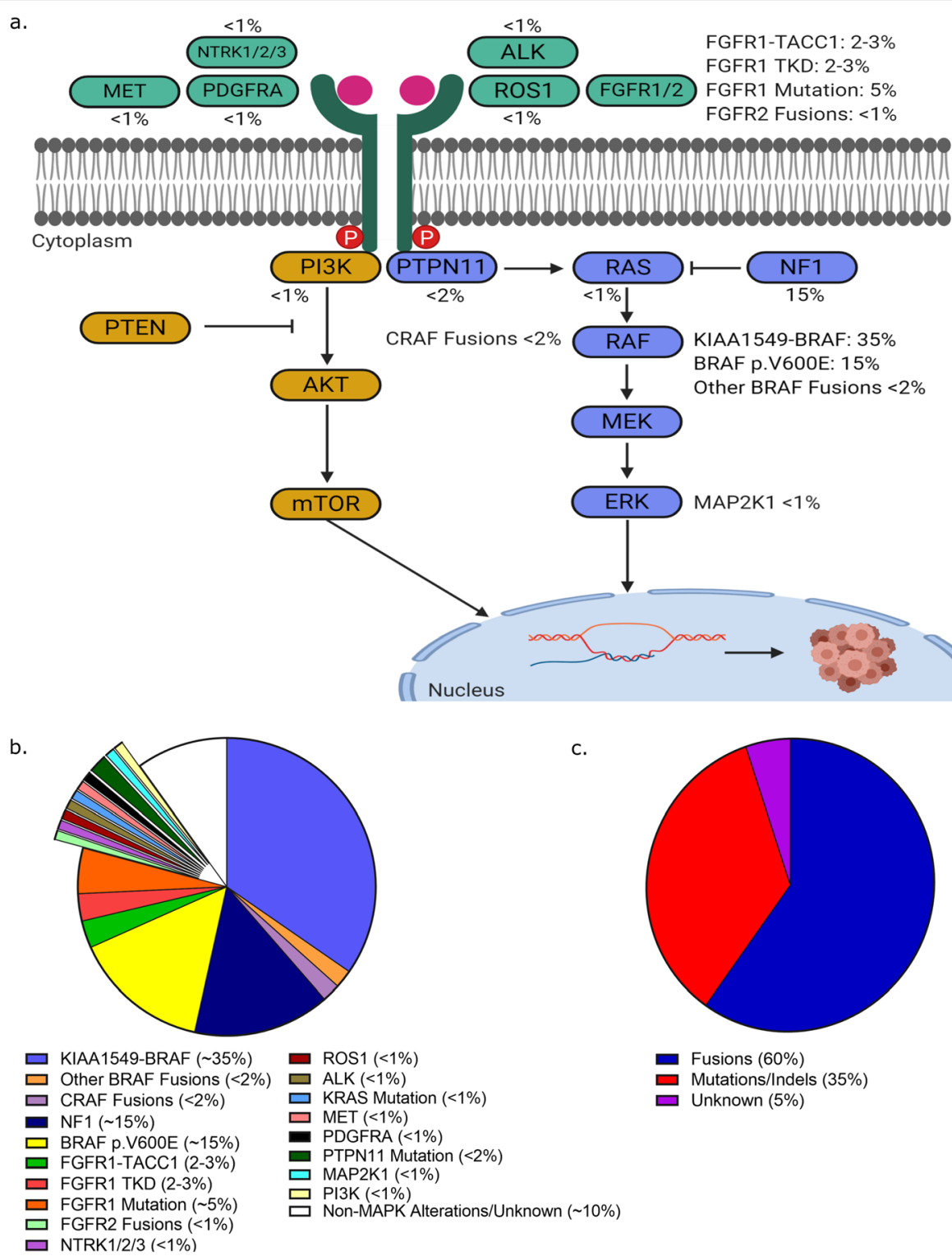

Fig. 2. a. Schematic of the RAS/MAPK alterations identified across pediatric low-grade glioma. b. Average frequencies of RAS/MAPK alterations identified in pediatric low-grade glioma at the population level. c. Alteration types identified in pediatric low-grade glioma

[186]. Due to its predilection for arising in highly circumscribed histologies (pilocytic astrocytoma) and in surgically amenable locations (cerebellum), tumors with a KIAA1549-BRAF fusion are often amendable to complete surgical resection and have excellent overall survival and rarely progress $[11,80,84,123]$. However, when arising in deep seated regions of the brain where complete surgical resection is not possible, progression is more common [123]. The presence of KIAA1549$B R A F$ can aid in tumor diagnosis as it is not found in adult-type diffuse glioma and, with rare exceptions, confirms a pLGG diagnosis [78, 116, 178, 181]. Furthermore, it is helpful in identifying tumors susceptible to targeted therapeutics (discussed further below).

\section{Other BRAF Fusions}

In addition to KIAA1549-BRAF, BRAF rearrangements involving other fusion partners including RNF130 [97], SRGAP [99], FAM131B [32], CLCN6 [97], GNAI1 [97], MKRN1 [97], GIT2 [81], and FXR1 [229] among others have also been documented. As with KIAA1549-BRAF, these fusions result in the removal of $B R A F \mathrm{~s}$ Nregulatory domain and result in constitutive upregulation of the RAS/MAPK pathway. As these fusions are extremely rare and often identified in isolated case studies, whether their impact on patient outcome differs from KIAA1549-BRAF remains unclear. However, in contrast to KIAA1549-BRAF, these non-canonical fusions are frequently observed in hemispheric and/or 

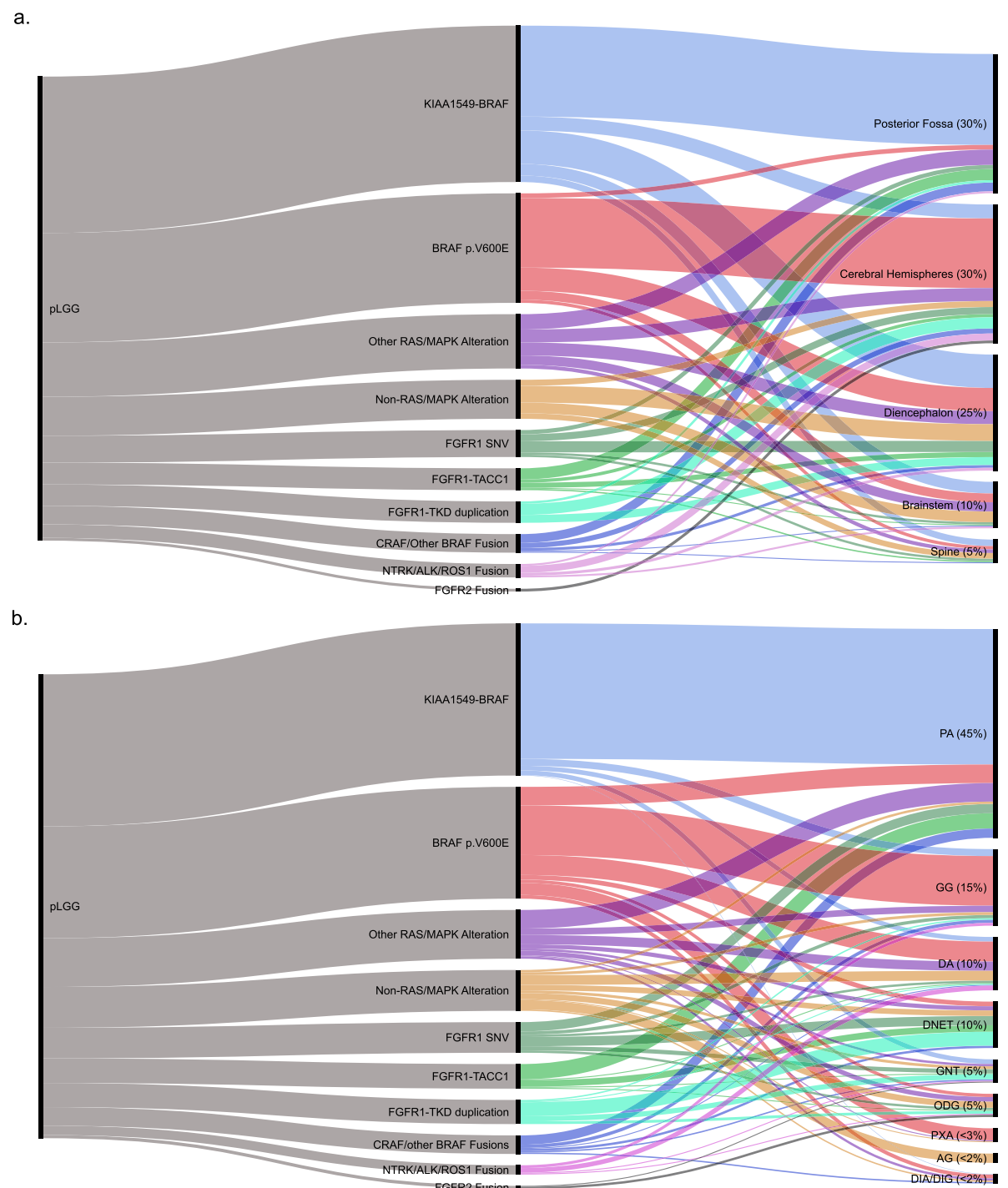

Fig. 3. Distribution of molecular alterations as it pertains to $\mathbf{a}$. tumor location and $\mathbf{b}$. tumor histology. Plots were created using https://rawgraphs. io Accessed December, 2019

brainstem lesions and tend to arise in older children and adolescents. Further, despite also primarily arising in PA, they are also seen in an array of less common histologies [32, 60, 81, 97, 229]. Whether these unique clinical features are related to a different mechanism of tumorigenesis remains to be investigated.

\section{BRAF p.V600E}

Mutations in BRAF, primarily in which a valine is replaced with a glutamic acid at position 600 (p.V600E), act as a phosphomimetic within the RAS/MAPK pathway, rendering it constitutively active [64, 222]. In pLGG, the prevalence of the BRAF p.V600E mutation varies notably depending on the histology and location of the tumor (Fig. 3a, b). Pleomorphic xanthoastrocytoma $(40-80 \%)[46,68,85,191]$, diffuse astrocytoma (30-
$40 \%)[190,191]$ and ganglioglioma (25-45\%) $[85,123$, $164,191]$ frequently harbor BRAF p.V600E, while in pilocytic astrocytoma $(5-10 \%)[85,123,191]$ or glioneuronal tumors (5\%) [191, 47, 49], BRAF p.V600E is less common. Supratentorial lesions are also more likely to harbor BRAF p.V600E as compared to cerebellar lesions, while the inverse is true for KIAA1549-BRAF (Fig. 3a) [34, 46, 49, 171]. Importantly, despite these enrichments, BRAF p.V600E is neither histologically nor spatially restricted $[47,123,171]$. In addition to p.V600E, rare cases of BRAF p.V600D and BRAF p.V504_R506dup have been described in desmoplastic infantile astrocytomas/gliomas and pilocytic astrocytoma, respectively [27, 72, 107].

As a group, pLGGs with BRAF p.V600E have worse OS and PFS compared to other pLGG $[28,35,50,123$, 
158]. Further, BRAF p.V600E pLGG, especially in the context of co-occurring CDKN2A deletions (discussed further below), are significantly more likely to transform into HGG; an event which may occur 10-20 years after the initial diagnosis [142]. While not exclusive to this entity, transformation has been most commonly describe for pleomorphic xanthoastrocytoma which has been suggested to be within the same family as epithelioid GBM $[4,63,210]$. These "pleomorphic xanthoastrocytomalike" GBM carry a better prognosis compared to other GBM, but are still significantly worse when compared to pLGG [117]. The increased likelihood of malignant behavior in pleomorphic xanthoastrocytoma and in BRAF p.V600E mutated tumors with $C D K N 2 A$ deletion has led to a debate regarding the prognostic significance of BRAF p.V600E alone [101]. Future studies utilizing extensive cohorts with long-term follow-up will be required to address these questions conclusively.

\section{FGFR 1}

FGFR1 is a receptor tyrosine kinase (RTK) that plays a key role in signal transduction via activation of its intramembranous tyrosine kinase domain (TKD) [69, 216]. While FGFR1 mutations and/or fusions are only present in $3 \%$ of adult GBM [176, 202], it is the second most commonly altered gene in pLGG. FGFR1 alterations in pLGG arise via three mechanisms: FGFR1 mutations, FGFR1-TACC1 fusions and FGFR1-TKD duplications [97, 171, 229]. FGFR1 mutations primarily consist of p.N546K and p.K656E and occur in 5-10\% of patients [97, 171, 229]. As with BRAF alterations, these are histologically and spatially enriched, most frequently arising in dysembryoplastic neuroepithelial tumors, other glioneuronal tumors, and in midline brain structures (Fig. 3a-b). In these tumor subtypes, FGFR1 mutations occur in up to $20 \%$ of patients, and in rare cases may be germline events [97, 136, 179, 191]. However, FGFR1 mutations have also been reported in pilocytic astrocytoma, oligodendroglioma, and other histologies, and therefore are not histologically restricted $[11,67,97,171,187$, 229]. FGFR1 TKD-duplication and FGFR1-TACC1 fusions have each been described in $2-3 \%$ of tumors, [97, 171, 187, 229]. As with FGFR1 mutations, FGFR1 TKDduplication is more common in dysembryoplastic neuroepithelial tumors and other glioneuronal tumors, while FGFR1-TACC1 is more common in pilocytic astrocytoma. However, neither of these alterations are histologically restricted, also appearing in oligodendroglioma and diffuse astrocytoma, for example (Fig. 3a-b) [97, 171, 187, 229]. All of these alterations result in FGFR1 autophosphorylation $[97,229]$, leading to up-regulation of the RAS/MAPK pathway. In contrast to $B R A F$ alterations, the upstream location of FGFR1 (and the other receptor tyrosine kinase alterations described below) can result in up-regulation of the PI3K/AKT/mTOR pathway as well as depicted in Fig. 2a.

Despite being the second most common alteration in pLGG, the clinical manifestations of FGFR1 alterations are still not well described. Becker et al., in their description of FGFR1 mutations in pilocytic astrocytoma, noted that mutated tumors had a worse prognosis than their wild-type counterparts [11]. Whether this worsened outcome is due to the alteration itself or the propensity for FGFR1 mutated tumors to arise in the midline is unknown. Importantly, FGFR1 mutations often contain additional alterations, most frequently a second event in FGFR1 resulting in an FGFR1 "dual hit" [97, 229]. In addition, co-occurring alterations in BRAF, KRAS, NF1, PTPN11 and H3F3A have also been reported [97, 171, 187, 229]. Except for $H 3 F 3 A$, whether these additional alterations impact patient prognosis is yet to be established. However, the propensity for FGFR1 mutations (but not TKD duplication or FGFR1-TACC1) to cooccur with additional alterations is interesting and may provide insight into the underlying pathogenesis of these tumors.

\section{CRAF Fusions}

Fusions involving CRAF (RAF1), a human homolog of the $\mathrm{v}$-raf gene implicated in cell proliferation and survival, are infrequently identified in pLGG, most commonly in pilocytic astrocytoma. These include QKIRAF1 [131, 229], FYCO-RAF1 [229], TRIM33-RAF1 [43], SRGAP3-RAF1 [98, 99], and ATG7-RAF1 [95, 96] among others. As with non-canonical $B R A F$ fusions, $C R A F$ fusions have been shown to up-regulate the RAS/MAPK pathway $[93,98,99]$. Due to the rarity of $C R A F$ fusions, their clinical implications are unclear.

\section{NTRK Fusions}

The neurotrophic tyrosine receptor kinase (NTRK) family of genes play key roles in CNS development [75, 213, 219] and has long been implicated in a variety of cancers [192, 213]. NTRK fusions have been identified in various histological subtypes of pLGG, albeit at very low frequencies. These alterations include SLMAP-NTRK2, TPM3-NTRK1, ETV6-NTRK3 and RBPMS-NTRK3 [97, $171,215,229]$. All these fusions are predicted to drive tumorigenesis via aberrant dimerization of the NTRK kinase domain, resulting in constitutive downstream activation that, at least in part, impacts both the RAS/ MAPK and PI3K/AKT/mTOR pathways [104, 108, 148]. These results have led to several clinical trials using targeted agents against NTRK (discussed below).

\section{KRAS Mutations}

A small subset of non-BRAF mutated pLGG harbor mutations in KRAS, an upstream molecule in the RAS/ 
MAPK pathway (Fig. 2). Reports on the frequency of KRAS mutations in pLGG range from 1-5\% and primarily arise in pilocytic astrocytoma [94, 95, 97, 164, 229]. Most frequently, these are p.G12D or p.Q61H/K, although one report noted both novel and dual KRAS mutations within 2 patients [97]. Importantly, KRAS mutations are also seen in high grade gliomas and therefore cannot be used as a diagnostic marker for pLGG. Given the success of inhibiting downstream effectors of KRAS mutations in other cancer types [74], identifying these mutations in pLGG may offer access to targeted treatment approaches.

\section{PTPN11 Mutations}

PTPN11 (or SHP-2) is a tyrosine phosphatase adaptor protein within the RAS/MAPK pathway known to cause Noonan syndrome [182]. With regards to pLGG, specifically pilocytic astrocytoma, PTPN11 alterations have been reported in approximately $2 \%$ of cases [95, 97]. Interestingly, in these studies $82 \%$ of PTPN11-mutant cases also harbored alterations in FGFR1, suggesting that the two are biologically linked. In the original report defining the mutation, the authors noted that PTPN11 over-expression alone did not significantly activate the RAS/MAPK pathway, but did when in the presence of FGFR1 mutations [97]. The authors suggested that PTPN11 alone was insufficient to promote transformation, but instead played a modifying role in FGFR1-mutant pLGG. Future work in GBM proposed that PTPN11 is essential for maintaining a glioma stem cell population during transformation [180] and for activating PI3K/ AKT/mTOR signalling [129]. This suggests that mTOR inhibitors may be more effective than RAS/MAPK inhibitors in PLGG harboring these alterations.

\section{ALK Fusions}

The anaplastic lymphoma kinase $(A L K)$ gene is thought to play a key role in the development and function of the nervous system and chromosomal alterations and gain of function mutations in it have been reported in a plethora of pediatric cancers [29, 30, 106, 137, 220]. These alterations are most commonly fusion events that result in ectopic expression of the ALK fusion protein [6]. This results in up-regulation of the RAS/MAPK and PI3K/AKT/mTOR pathways [73, 143]. Despite the frequency of $A L K$ alterations in pediatric cancer, reports of its presence in glioma are rare and often exist in isolated case reports $[1,147,152]$. The most frequently reported alterations are CCDC88A-ALK and PPP1CB-ALK, both resultant fusions from a larger chromothripsis event $[1$, 73, 147, 152]. Recently, $A L K$ alterations were shown to form a unique clinical subgroup of infantile glioma that require would likely benefit from a refined treatment approach [73].

\section{ROS1 Fusions}

ROS1 is an orphan tyrosine receptor with no known ligand nor definitive function despite speculation for a role in cell proliferation and differentiation. In pLGG, GOPC-ROS1 is the result of an intrachromosomal deletion that results in a constitutively active kinase fusion product sufficient to promote neoplastic transformation both in vitro and in vivo $[26,40]$. Although GOPC-ROS1 represents the most common ROS1 alteration in gliomas, CEP85L-ROS1, ZCCHC8-ROS1, and KLC1-ROS1 have also been reported [33, 40, 146]. The use of targeted agents against ROS1 in lung cancers has shown dramatic clinical efficacy $[54,198]$, which has resulted in interest regarding their use in glioma.

\section{MAP2K1 Alterations}

Alterations including p.Q56P and small in-frame deletions in MAP2K1 were frequent in a small cohort of multinodular and vacuolating neuronal tumors (MVNT) [163]. Within pLGG, this alteration appears to be enriched for this histological subtype, as follow-up work looking into the molecular landscape of ganglioglioma did not identify any further $M A P 2 K 1$ alterations [164]. However, $M A P 2 K 1$ is altered in other non-pLGG tumors including lung and colorectal cancers and thus, as with $K R A S$, is not specific to these entities. These alterations in other malignancies have shown up-regulation of the RAS/MAPK pathway and may have a similar mechanism in MVNT $[18,23,156]$.

\section{Other Rare RAS/MAPK Alterations}

Recurrent alterations involving FGFR2/3 (rather than the more frequent FGFR1) have been identified in a recently defined tumor type, PLNTY, which carries a good prognosis [88]. These occur exclusively as fusion events, most commonly as FGFR2-KIAA1598 and FGFR2-CTNNA3 but also rarely as FGFR3-TACC3. In contrast to FGFR1-TACC1, FGFR3-TACC3 is extremely rare in pLGG, but arises in $\sim 3 \%$ of IDH1/2 wild-type adult GBM. Therefore, paying close attention to the histologic features is important for tumors harboring this fusion $[45,152]$.

PDGFR $\alpha$ mutations have been reported in low grade glioneuronal tumors of the septum pellucidum [204], despite more typically being associated with HGG in the context of other mutations [109, 193, 207, 226, 227]. The clinical implications of these rare alterations are not yet fully understood.

\section{Non-RAS/MAPK Related Alterations in pLGG}

The degree of molecular data converging on the RAS/ MAPK pathway has justifiably led to speculation that pLGG is a "one-pathway" disease [34, 96, 149, 229]. However, despite this, several alterations with 
seemingly no direct impact on RAS/MAPK signalling have also been described. It may be that these aberration do, in fact, impact this pathway via mechanisms not yet discovered. We discuss these non-RAS/MAPK alterations below.

\section{MYB alterations}

Myb proto-oncogene protein $(c-M Y B)$ is a member of the myeloblastosis family of transcription factors named after the avian myeloblastosis virus gene ( $\mathrm{v}$ Myb) which causes myeloid leukemia in chickens. It plays an important role in the control of proliferation and differentiation of hematopoietic and other progenitor cells and has well described proto-oncogenic functions in both human leukemia and solid tumors where it is thought that super-enhancers to $c-M Y B$, as a consequence of chromosomal translocation, cause overexpression of $c-M Y B[160,230]$. MYB's involvement in pLGG was first described in 2010 by Tatevossian et al. who identified $M Y B$ amplification in 2 of 14 diffuse astrocytomas and a focal deletion of the terminal region of $M Y B$ in 1 of 2 angiocentric gliomas [212]. The authors concluded that $60 \%$ of diffuse astrocytomas displayed MYB up-regulation at the protein level, but were unable to identify a unifying genetic event responsible for the observation. This finding was later confirmed, when $22 \%(8 / 36)$ of diffuse cerebral gliomas, including diffuse astrocytoma and angiocentric glioma, were shown to have a $M Y B$ 3 ' truncating fusion or, less commonly, amplification resulting in elevated expression at the protein level [229]. More recently, Bandopadhayay et. al. published that $10 \%(16 / 172)$ of their pLGG cohort contained $M Y B$ alterations, most commonly as MYB-QKI fusions, including 19/19 (discovery and validation cohorts) angiocentric gliomas [8]. This fusion was shown to likely function via a tripartite mechanism of MYB protein activation, $M Y B$ overexpression and the loss-of-function of $Q K I$ [8]. Work investigating the genetics of uncommon low-grade neuroepithelial tumors showed that $87 \%$ and $41 \%$ of angiocentric glioma and diffuse astrocytoma, respectively, harbored $M Y B$ alterations [171]. MYB-ESR1, MYB-PCDHGA1, MYB-LOC105378099, MYB-MMP16, MYB$L O C 154902$, and MYB-MAML2 in addition to MYBQKI have also been identified [31, 171, 229]. Importantly, $M Y B$ alterations are histologically restricted to angiocentric and diffuse gliomas.

\section{MYBL1 alterations}

$M Y B L 1$ (MYB Proto-Oncogene Like 1) is a closely related family member of $M Y B$, and is thought to likewise act as a transcriptional regulator critical for proliferation and differentiation. Although commonly grouped together due to their overlapping biological function, much less is known about MYBL1 compared to $M Y B$-driven tumors. Originally described in Ramkissoon et. al. in $28 \%(5 / 18)$ of diffuse astrocytomas, these MYBL1-driven tumors showed a partial duplication with truncation of its C-terminal regulatory [174]. The common breakpoint immediately preceding the C-terminal regulatory domain in these cases suggest the potential formation of a functional, truncated gene product. However, the concise downstream functional consequence of this event remains to be fully elucidated [174]. More recent reports of MYBL1 alterations in pLGG suggest MYBL1 alterations may be even rarer, being found in $2 / 17$ (12\%) [171], 7/50 (14\%) [8], and 1/17 (6\%) [229] diffuse astrocytomas. No other histological diagnoses have been reported to harbor $M Y B L 1$ alterations.

$M Y B$ and $M Y B L 1$ alterations were originally described in diffuse gliomas of childhood. They are more likely to arise in young children (median age 5 years) and are significantly enriched for the cerebral hemispheres, although infrequently they occurred in the diencephalon or brainstem [31, 25, 38]. A recent single-centre pediatric study showed a 10-year OS and PFS of $90 \%$ and $95 \%$, respectively, suggesting that these lesions are indolent [31]. These alterations have also been described in the adult age group where they represented $\sim 50 \%$ of so-called isomorphic diffuse glioma (a subtype of IDH1 wild-type, BRAF p.V600E negative diffuse astrocytoma) in both children and adults [223]. These tumors, despite their diffuse astrocytoma morphological features, had a good prognosis. When clustered on t-SNE via methylation analysis, both $M Y B$ and MYBL1 tumors cluster together, and the authors conclude that they reflect a single tumor entity [31]. However, this hypothesis merits further investigation as more of these rare cases, in particular those harboring MYBL1 alterations, are reported.

\section{IDH1 Mutations}

Mutations in IDH1 are present in $~ 70 \%$ of grade II, grade III, and secondary GBM in adults, most frequently at position p.R132 [7, 15, 77, 228]. Despite their frequency in adults, $I D H 1$ mutations in pediatric glioma are rare, with reports ranging from $0-17 \%$ of cases [7, $41,77,169,228]$. As with adult tumors, the IDH1 mutation is usually in the context of either $1 \mathrm{p} / 19 \mathrm{q}$ codeletion or is associated with TP53 and ATRX mutations and as such, likely represent the lower end of the age spectrum of adult-type IDH-mutant glioma [103, 130]. There is a significant correlation between IDH1 alterations and patient age. In one report, IDH1 mutations were identified in $5 \%$ of pediatric gliomas which collectively had a median age of 16 [41]. Likewise, a report 
from the Children's Oncology Group noted a 16\% incidence of IDH1 mutations, all of which occurred in patients over the age of 14 [169]. In adults, IDH1 mutations are associated with a better prognosis and response to chemotherapy as compared to IDH1/2 wildtype glioma [76, 86, 140, 151, 188]. While the clinical impact of $I D H 1$ mutations in children is far less understood, it is likely that they will not behave in the same indolent way as most other pLGG over the long term. It is plausible that these tumors are in fact adult malignancies that have been identified early. As such, these tumors should be more closely followed than true pLGG [92].

\section{H3F3A Mutations}

Mutations in histone variant H3F3A (H3.3) were first described in pediatric high grade glioma, specifically diffuse intrinsic pontine glioma (DIPG), where they are present in approximately $65 \%$ of tumors $[109,134,193$, 207, 226, 227]. H3.3 p.K27M is exclusively observed in tumors arising in the midline, including the pons, diencephalon/thalamus and spinal cord [66, 109, 134, 193, 207, 226, 227]. Although more frequent in HGG, H3.3 p.K27M has been reported in pLGG including pilocytic astrocytoma [82, 153], ganglioglioma [102, 112, 158] and diffuse astrocytoma $[187,205]$. In one series of pediatric thalamic glioma, H3.3 p.K27M was noted in $12 \%$ of low grade cases [187]. Interestingly, H3.3 p.K27M has been shown to co-occur with additional hotspot mutations, including BRAF p.V600E, FGFR1 p.N546K or p.K656E, and NF1 mutations [102, 112, 158, 187]. Patients with H3.3 p.K27M pLGG have the potential to live longer than patients with $\mathrm{H} 3.3$ p.K27M glioma with high grade histologic features. Indeed, there are reports of survival of up to 10 years post-surgery in rare cases [82, 102, 112, 153 158], although most patients succumb to their disease within 1-3 years. In this regard, despite their comparatively longer survival, these tumors tend to mimic the clinical impact of H3.3 p.K27M in HGG in that they invariably progress and cause death, starkly contrasting the excellent survival of non-H3.3 p.K27M mutant pLGG as described above.

\section{Secondary Alterations in pLGG CDKN2A Deletion}

Homozygous and hemizygous losses involving 9p21 are frequent in adult infiltrating glioma and GBM [13, 150, 163]. One of the consequences of this deletion is the loss of the tumor suppressor $C D K N 2 A$, which endogenously functions as a G1 cell-cycle regulator [125, 184]. Homozygous deletion of CDKN2A is also observed in pLGG, albeit at a lower frequency than in adult glioma $[10,161$, 162, 165, 170]. Reports suggest that CDKN2A loss ranges in frequency from 6-20\% in pLGG, with significant enrichment in pleomorphic xanthoastrocytoma $[17,51,84,190]$. Likewise, CDKN2A deletion frequently co-occurs with BRAF p.V600E, suggesting that it likely acts as a second molecular hit, promoting escape from cell cycle regulation $[17,84,85,91,173$, 190]. Tumors harboring both BRAF p.V600E and CDKN2A deletion comprise a distinct clinical subtype of pLGG prone to transformation into secondary HGG [142]. This is in line with reports showing that cooccurrence of $C D K N 2 A$ deletion with BRAF p.V600E is associated with escape from oncogene-induced senescence $[91,173]$ and with having a worse OS and PFS [85]. Interestingly, several reports have also shown that pediatric grade I gliomas harboring CDKN2A loss, despite their rarity, have a more aggressive clinical course consistent with that of a higher histological grade [173, 190] and co-occurrence of CDKN2A deletion with $B R A F$ fusions has been described in anaplastic astrocytoma with piloid features [178]. As such, pLGG with CDKN2A deletions, especially in the context of BRAF p.V600E or with possible high grade histologic features, should be considered as high risk tumors that warrant close clinical follow-up.

\section{Molecular Tests and Platforms for profiling pLGG}

Currently, a wide array of clinically-certified laboratory methods are used to molecularly profile pLGG. However, no "gold standard" exists for testing the array of potential molecular events and various strategies may be used depending on tissue quality/quantity and budget. As detailed above, one should strive to have tools which can identify SNVs and gene fusions. Simple and robust tests which can be used to detect common alterations such as BRAF fusions and BRAF p.V600E allow molecular characterization of almost two thirds of pLGG.

Below, we discuss some of the common testing strategies used to molecularly profile pLGG and include their tissue requirements, cost, turn-around time, and targetspecific applicability (Table 2).

\section{Immunohistochemistry}

Immunohistochemistry (IHC) is a simple and robust test which can identify specific alterations in most laboratories. IHC is capable of detecting protein specific expression indicative of the tumor's underlying mutational status in a timely, cost-effective manner while requiring very little tissue in the process. With respect to PLGG, IHC has been faithfully utilized in the detection of BRAF p.V600E [21], H3.3 p.K27M [221] and IDH1 p.R132H [22] and can be used on formalin-fixed-paraffin-embedded (FFPE) tissue. However, this approach is limited to those alterations with available antibodies. 


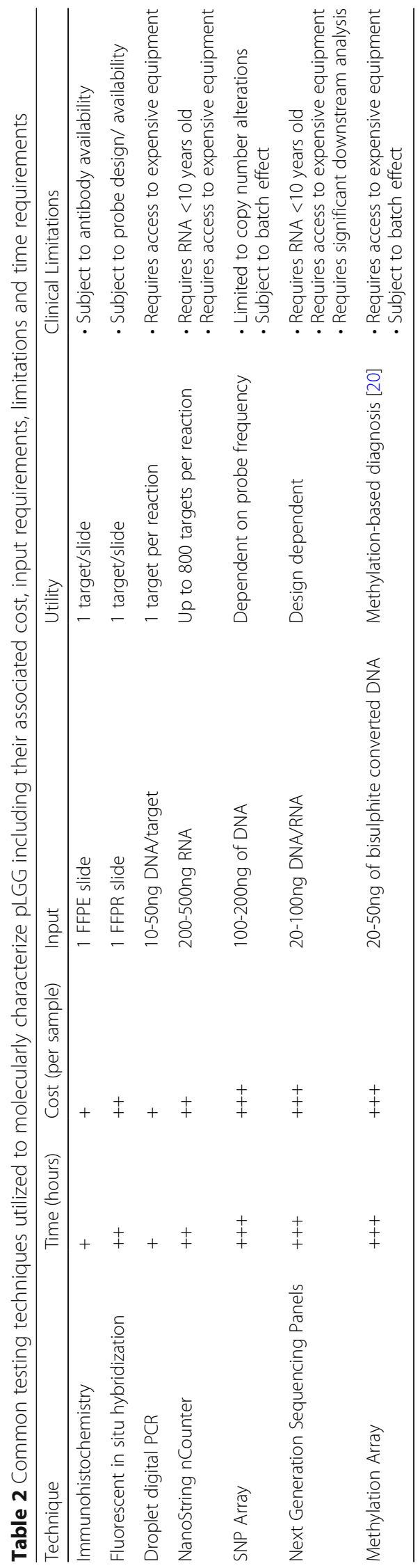




\section{Fluorescent in situ Hybridization}

Fluorescent in situ hybridization (FISH) allows for visualization of both gene fusions and copy number events at a single cell resolution. In pLGG, FISH has been used in the identification of BRAF [214], FGFR1 [179], ALK/ROS1/NTRK1/2/3 fusions [73], and MYB/ $M Y B L 1$ alterations [174, 212]. It can also be used for identifying co-occurring $C D K N 2 A$ deletions. FISH is widely available and can be used on FFPE material but is relatively labor-intensive, and can only test for a single alteration at a time.

\section{Droplet Digital PCR}

Point mutations can be also detected using polymerase chain reaction (PCR) techniques. If available, the advantage of droplet-digital PCR (ddPCR) is its ability to faithfully detect mutations at very low variant allele frequencies related to low quality or highly diffuse input material. In addition, ddPCR's ability to do high throughput testing makes the test affordable when run at capacity. In this process, single fragments of DNA are partitioned into oil-based droplets and amplified using standard TaqMan probes designed against the desired target [172]. As each individual droplet is devoid of competition, each DNA fragment is amplified, allowing for unparalleled sensitivity. ddPCR can identify not only point mutations such as BRAF p.V600E [123], H3.3 p.K27M [187], IDH1 p.R132H [187], and FGFR1 p.N546K and p.K656E [58] but also CDKN2A deletions [123], KIAA1549-BRAF [5], and FGFR1 TKD-duplication [58] based on copy number comparisons. This technique is very robust on degraded DNA, including from FFPE material, and requires minimal technical hands-on time. However, it is difficult to multiplex and requires access to expensive equipment.

\section{NanoString nCounter}

The NanoString nCounter system is a hydridization based platform capable of detecting fusion transcripts in a multiplexed fashion [186]. NanoString panels can be used to screen for the common fusions such as those involving BRAF (including both the canonical KIAA1549$B R A F$ and the non-canonical fusions described above) and FGFR1-TACC1 [186] as well as for rarer fusions including those involving $A L K, R O S 1, N T R K$, and MET [73]. This technology is robust on FFPE material, requires minimal technical hands-on time and bioinformatic analysis is relatively simple. However, input requirements are relatively high (200-500ng of RNA), the fusion partner and exact breakpoint must be known and it requires access to expensive equipment.

\section{SNP Array}

In cases where no specific alterations can be found using the gene specific tools, or when copy number alterations have a role in tumor management, genome-wide SNP arrays can be used. SNP arrays are a probe-based molecular profiling technique optimized for the detection of copy number variants. Their use in pLGG molecular profiling includes the identification of $B R A F$ and FGFR fusions, $M Y B$ and $M Y B L 1$ alterations and $C D K N 2 A$ deletions. SNP arrays are robust with FFPE material, but require expensive reagents, long technical hands-on time and batching of samples as well as a moderate amount of input material (100-200ng of DNA) and access to expensive equipment.

\section{Next generation sequencing panels}

In recent years, the use of next-generation sequencing (NGS) platforms for the molecular characterization of solid tumors has gained significant popularity [113, 175, 209]. These platforms range from approximately 300500 gene targets (or more) and often include most of those altered in pLGG. Sequencing based approaches have the benefit of simultaneous detection of most clinically relevant alterations in a single test from which diagnostic, prognostic and therapy decisions can be made. However, tissue quality requirements, which are generally higher as compared to the other technologies, technical hands-on time and downstream analysis are more complicated and time-consuming leading to longer turn-around-times and cost. Access to expensive equipment is also required, all of which limit the use of these approaches globally. Nevertheless, in the cases where the tools above cannot identify the pLGG molecular driver, NGS approaches are highly advantageous.

\section{Methylation Profiling}

DNA methylation profiling is another tool which can aid in the diagnosis of tumors arising in the CNS [20]. This method is particularly useful in aiding the diagnosis of difficult tumor entities and is robust on FFPE material. In addition, current arrays can detect copy number alterations, albeit at a lower resolution than SNP arrays. However, the utility of the methylation classifier may be less robust in pLGG, possibly due to frequent inclusion of normal tissue in these tumors [20]. Furthermore, methylation profiling remains expensive, is subject to batch effects, and must be run in sets of 8 . Further, the utility of methylation profiling as it pertains to tumor diagnosis requires further investigation.

\section{Molecular pLGG diagnostic algorithm}

Given the array of molecular alterations and their overlap amongst different tumor histologies, devising a simple testing recommendation for pLGG can be difficult. Ultimately, as proposed by Miklja et. al. [141], there are two primary approaches to the problem (i) sequential testing of specific alterations in a tier-based approach or (ii) upfront 
NGS panels optimized for pLGG. The latter may be used in centers with access to this technology and for whom cost is not an issue. For other centers the use of a sequential testing strategy is largely supported by the fact that the vast majority of pLGG harbor a single molecular driver within a subset of recurrently altered genes. These events primarily occur as either gene fusions or mutations, but almost never both. Rarely, exceptions arise where multiple mutations, either within the same gene or in other traditional pLGG targets, arise. These are almost exclusively observed with mutations and not gene fusions. The crux of this strategy lies in its ability to accurately identify a molecular driver prior to the number of tests conducted exceeding the cost and turn-around-time of an NGS based approach. A possible testing strategy highlighting the most probable molecular alterations present based on the tumor's clinical features is included in Fig. 4.

\section{Targeted Molecular Therapies for pLGG BRAF Inhibitors}

First generation $B R A F$ inhibitors including dabrafenib and vemurafenib have shown excellent results in melanoma patients harboring BRAF p.V600E and are now being investigated for their utility in pLGG $[79,206]$. A series of case reports utilizing these agents in a single agent approach showed excellent results with most reporting a complete response [2, 24, 42, 121, 185, 203]. These findings were recently confirmed in a larger cohort of BRAF p.V600E tumors, in which either of these BRAF inhibitors induced significant cytoreduction and prolonged survival in patients [123]. These results led to a multi-institute phase I clinical trial, where initial findings using dabrafenib reported an impressive overall response rate of $41 \%$ [110] A follow-up trial optimizing the dosing safety and tolerability is currently underway (NCT01677741). Despite their efficacy in BRAF p.V600E tumors, first generation $B R A F$ inhibitors result in paradoxical activation of RAS/MAPK signalling when used in KIAA1549-BRAF or BRAF wild-type tumors [201]. This was the case in a trial of sorafenib, which caused accelerated tumor growth and resulted in the early termination of the trial [105]. To rectify this issue, second generation "paradox-breaker" agents were designed to inhibit $B R A F$ without causing paradoxical RAS/MAPK activation [217]. Of note, CRAF fused pLGG were unresponsive to both first and second generation $B R A F$ inhibitors [93]. This was attributed to the robust proteinprotein interactions mediated by the CRAF fusion partners [93]. This highlights the necessity of careful molecular characterization of pLGG prior to making treatment decisions, and emphasizes the risk of conducting trials without proper molecular characterization.

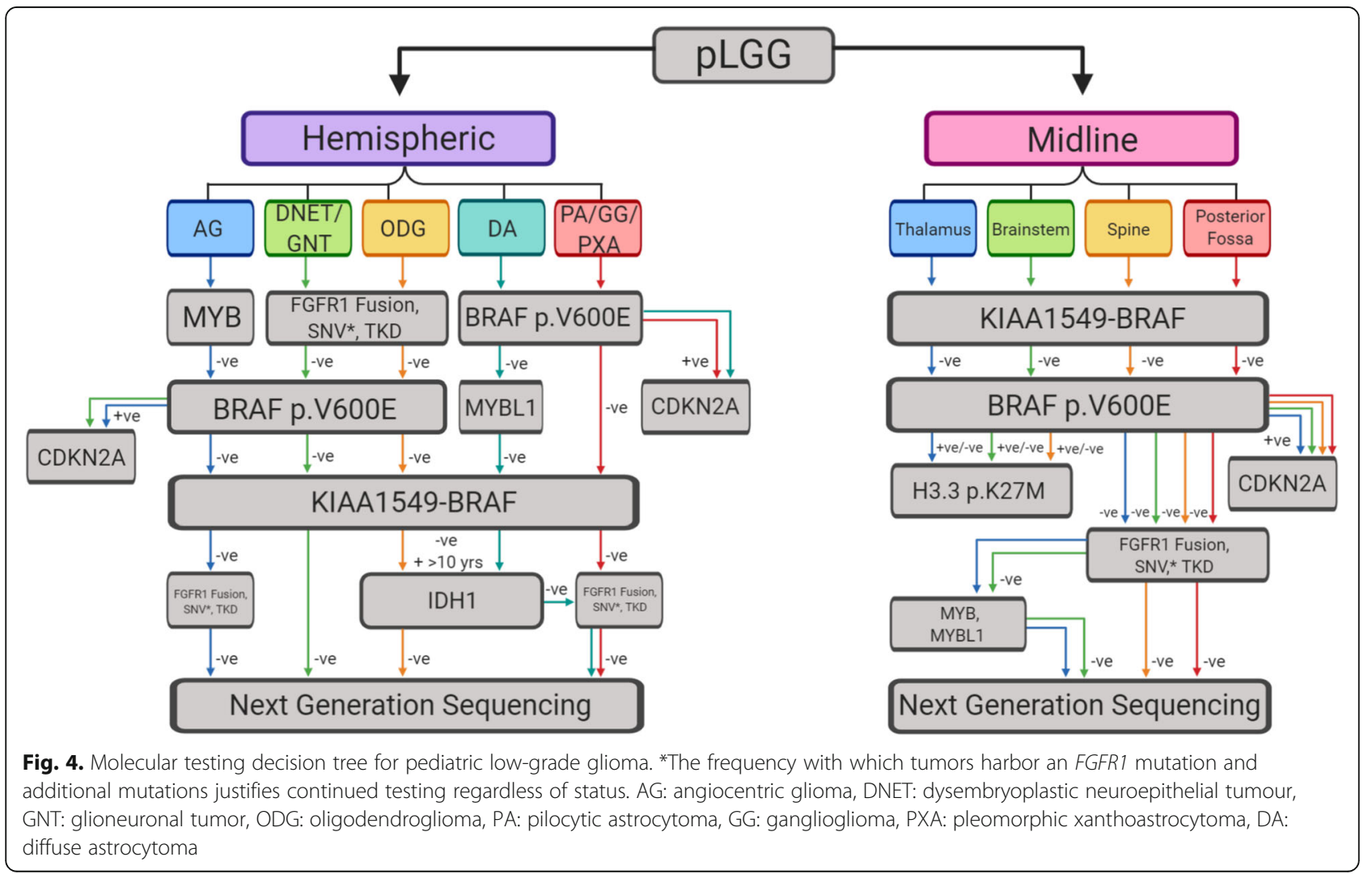




\section{MEK Inhibitors}

For pLGG that are not suitable for type I BRAF inhibitors (NF1-pLGG, KIAA1549-BRAF fused, etc.), MEK inhibition has emerged as a promising therapeutic strategy. Currently, four MEK inhibitors including selumetinib $[9,56)]$, trametinib (NCT03363217), cobimetinib (NCT02639546), and binimetinib (NCT02285439) are at various stages of clinical testing. For selumetinib, both phase I and II trials have been completed $[9,56]$. The phase I study focussing on NF1-associated and sporadic refractory or progressive pLGG showed that $32 / 38$ patients exhibited either stability or reductions in tumor size [9]. Similar results were seen in a Phase II study, where use of selumetinib in recurrent pLGG boasted impressive results, with $40 \%$ of NF1 patients achieving partial response and only 1 patient progressing while on treatment [56]. Given these positive results, efforts to evaluate the use of selumetinib upfront in newly diagnosed patients both as a single agent or in combinations are under way. The trial of trametinib involving 6 patients resulted in 2 partial and 3 minor responses, while 1 patient had progressive disease [115].

\section{FGFR1 Inhibitors}

Due to its functional importance and frequent implications in cancer, multiple small molecular inhibitors of FGFR have been developed, some of which are in clinical trials for an array of malignancies. These include AZD4547 (NCT02824133) for treatment of malignant glioma harboring FGFR-TACC fusions [65] and several others previously reviewed [36]. Results from these trials will inevitably influence the applicability of these agents in pediatric glioma.

\section{ALK/ROS1/NTRK Inhibitors}

Alterations in ALK, ROS1 and NTRK are relatively rare in pLGG. Conveniently, alterations in these genes are common in adult malignancies including lung and colorectal cancer and as such, targeted agents with federal approval have already been developed and tested. These include Crizotinib (NCT00939770) [144], ceritinib (NCT02336451) [111], and cabozantinib (NCT00704288) [224], as well as many investigational agents, such as brigatinib (ALK/ROS1) [39], entrectinib (ROS1/TRK) [128], and larotrectinib (TRK) [83, 194], the latter of which was recently approved in the treatment of TRK-altered cancers (NCT02122913) [83]. In pediatric glioma specifically, both entrectinib and larotrectinib have shown potent anti-tumor effects (NCT02637687, NCT02576431) [52, 53, 120]. These results have led to a current phase I/Ib study being conducted in pediatrics to evaluate Entrectinib in primary CNS tumors (NCT02650401).

\section{The Future of pLGG Classification}

The importance of molecular testing in tumor diagnostics is increasingly recognised and became formalised for brain tumors in the most recent WHO classification [132]. As we gain a better understanding of the molecular underpinnings of pLGG, it is becoming evident that, while certain histologies may be enriched for particular molecular events (and vice versa), they are not exclusively associated with a particular event. Furthermore, while classic morphologies exist for the entities encompassed within the umbrella of pLGG, there remain cases with overlapping features between histologic categories, as was discussed above. Importantly, whether a particular molecular event carries the same prognostic significance across different pLGG entities is currently unclear. Given this, a layered diagnostic approach is recommended where both the histologic classification and molecular findings are reported in an integrated diagnosis [133]. Most importantly, pLGG need to be distinguished from their adult-type counterparts as both clinical management and long term outcome are drastically different.

A comprehensive risk based classification of pLGG lies in an integrated model, utilizing clinical, imaging and molecular information to concisely categorize tumors based on their potential clinical risk (Fig. 5) [95, 97, 123, 171, 229, unpublished data]. The scheme we propose here attempts to incorporate these factors into one tool. For example, a pLGG with typically benign histology, a KIAA1549-BRAF fusion, and arising in a child between 3-12 years would typically be viewed as low risk and a "watch and wait" strategy may be employed, followed by less aggressive therapies if the tumor were to progress. In contrast, a tumor in an unfavorable location or highly disseminated with high risk molecular features will require close clinical follow-up and a more aggressive therapeutic approach (Fig. 5). This schematic approach would also allow for amendments incorporating adjunct strategies such as the methylation classifier [20] or other novel molecular targets upon their discovery.

\section{Conclusion}

The era of precision medicine for pLGG has arrived. Molecular stratification of pLGG resulting in significant clinical implications is currently available and has been seen in trials for specific inhibitors such as BRAF p.V600E- and MEK-inhibitors. The expected availability of FGFR-targeted agents, as well as other tyrosine kinase inhibitors for rare fusions, makes precision diagnostics key to the management of these patients. Indeed, the current National Cancer Institute-Children's Oncology Group Pediatric MATCH trial (NCT03155620) aims to match actionable mutations to 9 investigational therapies, providing a glimpse into the future of pLGG treatment. In this context it is important to be aware of 


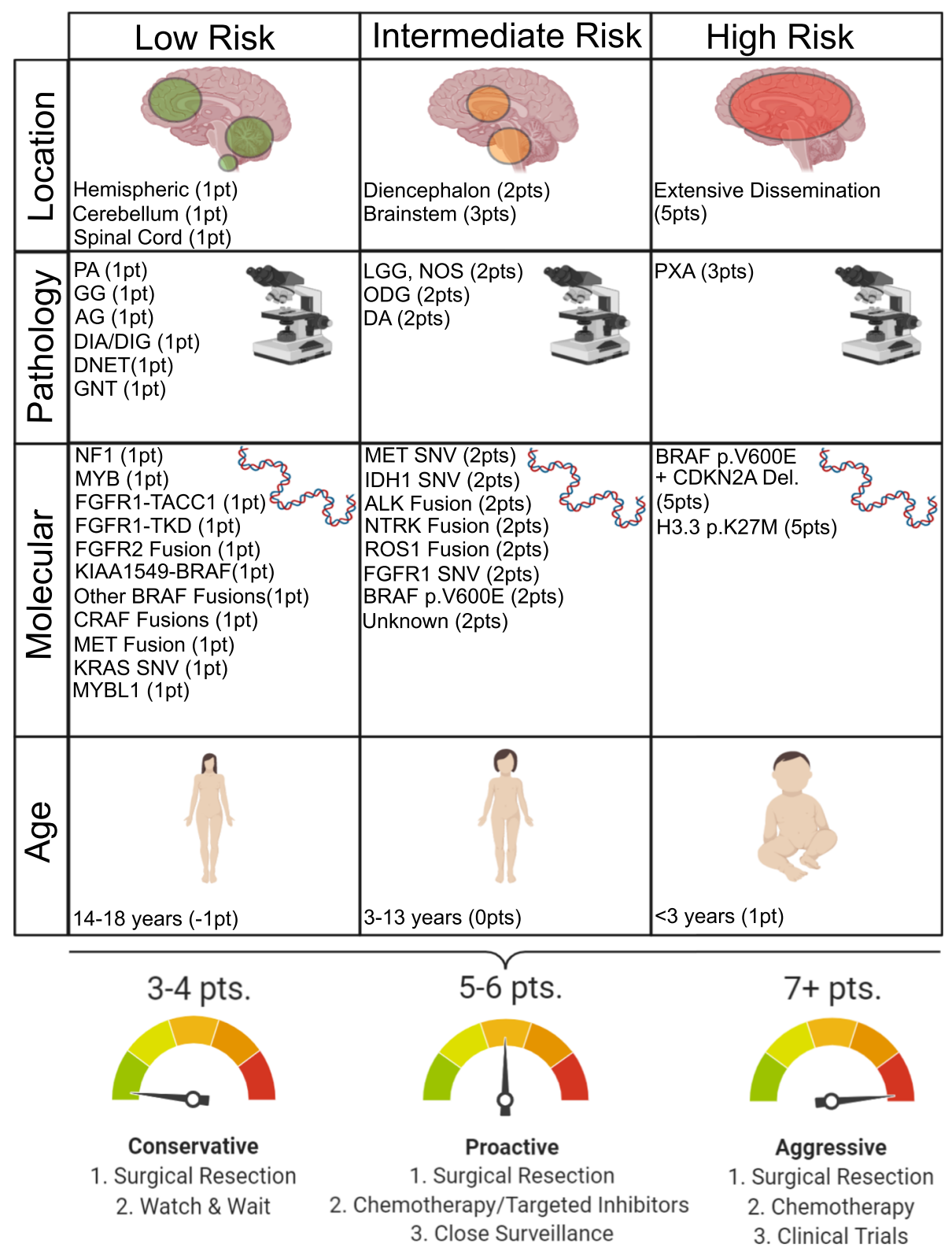

Fig. 5. Risk association for clinical and molecular features of pediatric low-grade glioma. Associated points are to be totaled for tumor location, histology, age at diagnosis and molecular driver. Point totals denote a risk association accompanied with clinical suggestions for proper tumor management. AG: angiocentric glioma, DNET: dysembryoplastic neuroepithelial tumour, GNT: glioneuronal tumor, ODG: oligodendroglioma, PA: pilocytic astrocytoma, GG: ganglioglioma, PXA: pleomorphic xanthoastrocytoma, DA: diffuse astrocytoma, DIA/DIG: Desmoplastic infantile astrocytoma/ganglioglioma, LGG, NOS: low-grade glioma, not otherwise specified

which methods are available to be used that are not reliant on expensive NGS-based technologies, and here we provide a testing pipeline to aid in testing decisions. Importantly, molecular stratification is only one factor influencing the behavior of pLGG. Other factors such as age, tumor location, and histopathology are required to inform a comprehensive approach to prognostication and treatment of pLGG. We therefore propose a pLGG risk classification schema that utilizes the breadth of clinical and molecular information available to best equip clinicians as we transition to this new era of pLGG classification and treatment.

\section{Abbreviations}

CNS: Central nervous system; ddPCR: Droplet-digital polymerase chain reaction; DIPG: Diffuse intrinsic pontine glioma; FFPE: Formalin-fixed-paraffinembedded; FISH: Fluorescent in situ hybridization; GBM: Glioblastoma; HGG: High-grade glioma; H\&E: Hematoxylin and eosin stain; IHC: Immunohistochemistry; LGG: Low-grade glioma; MRI: Magnetic resonance imaging; MVNT: Multinodular and vacuolating neuronal tumors; NF1: Neurofibromatosis Type I; NGS: Next generation sequencing; NTRK: Neurotrophic tyrosine receptor kinase; OS: Overall survival; 
PCR: Polymerase chain reaction; PFS: Progression-free survival; pLGG: Pediatric-type low-grade glioma; PLNTY: Pleomorphic neuroepithelial tumor of the young; RAS/MAPK: RAS-mitogen-activated protein kinase; RTK: Receptor tyrosine kinase; SNV: Single nucleotide variant; TKD: Tyrosine kinase domain; WHO: World Health Organization

\section{Acknowledgements}

We thank colleagues Liana Nobre, Julie Bennett and Javal Sheth for their contributions to this work.

\section{Authors' contributions}

SR extracted data, prepared figures and tables, and wrote the main text of the article. UT and $\mathrm{CH}$ prepared the article. All authors read and approved the final manuscript

\section{Funding}

This work was supported by endowed funds from the Government of Canada through Genome Canada and the Ontario Genomics Institute (OGI121): A Kid's Brain Tumor Cure; Brain Tumour Research Assistance and Information Network; The Pediatric Low-Grade Astrocytoma Foundation; Meagan's Walk; B.r.a.i.n.child Canada; Canadian Cancer Society (Grant \# 702296); Canadian Institute of Health Research (Grant \# 159805). S. R holds awards from Restracomp Scholarship and Fellowship funds from the Garron Family Chair in Childhood Cancer Research at The Hospital for Sick Children; Canadian Institute of Health Research (CGS-M) scholarship; Ontario Graduate Scholarship.

\section{Availability of data and materials}

The source of all data and material are cited in the manuscript. Availability of these are governed by the originating authors and source.

\section{Ethics approval and consent to participate}

Not applicable.

\section{Consent for publication}

Not applicable.

\section{Competing interests}

The author's declare that they have no competing interests.

\section{Author details}

${ }^{1}$ Arthur and Sonia Labatt Brain Tumour Research Centre, The Hospital for Sick Children, 555 University Avenue, Toronto, ON M5G 1X8, Canada. ${ }^{2}$ Department of Laboratory Medicine and Pathobiology, University of Toronto, Toronto, ON, Canada. ${ }^{3}$ Division of Pathology, The Hospital for Sick Children, Toronto, ON, Canada. ${ }^{4}$ Division of Haematology and Oncology, The Hospital for Sick Children, Toronto, ON, Canada. ${ }^{5}$ Department of Medical Biophysics, University of Toronto, Toronto, ON, Canada.

\section{Received: 30 January 2020 Accepted: 21 February 2020}

\section{1.}

\section{References}

1. Aghajan Y, Levy ML, Malicki DM, Crawford JR (2016) Novel PPP1CB-ALK fusion protein in a high-grade glioma of infancy. BMJ Case Rep. 2016. pii: bcr2016217189. https://doi.org/10.1136/bcr-2016-217189

2. Aguilera D, Janss A, Mazewski C, Castellino RC, Schniederjan M, Hayes L et a (2016) Successful Retreatment of a Child with a Refractory Brainstem Ganglioglioma with Vemurafenib. Pediatr Blood Cancer 63(3):541-543. https://doi.org/10.1002/pbc.25787

3. Aisner DL, Newell KL, Pollack AG, Kleinschmidt-Demasters BK, Steinberg GK, Smyth LT et al (2014) Composite pleomorphic xanthoastrocytomaepithelioid glioneuronal tumor with BRAF V600E mutation - report of three cases. Clin Neuropathol 33(2):112-121. https://doi.org/10.5414/NP300679

4. Alexandrescu S, Korshunov A, Lai SH, Dabiri S, Patil S, Li R et al (2016) Epithelioid Glioblastomas and Anaplastic Epithelioid Pleomorphic Xanthoastrocytomas--Same Entity or First Cousins? Brain Pathol 26(2):215223. https://doi.org/10.1111/bpa.12295

5. Appay R, Fina F, Macagno N, Padovani L, Colin C, Barets D et al (2018) Duplications of KIAA1549 and BRAF screening by Droplet Digital PCR from formalin-fixed paraffin-embedded DNA is an accurate alternative for
KIAA1549-BRAF fusion detection in pilocytic astrocytomas. Mod Pathol 31(10):1490-1501. https://doi.org/10.1038/s41379-018-0050-6

6. Armstrong F, Duplantier MM, Trempat P, Hieblot C, Lamant L, Espinos E et al (2004) Differential effects of X-ALK fusion proteins on proliferation, transformation, and invasion properties of NIH3T3 cells. Oncogene. 23(36): 6071-6082

7. Balss J, Meyer J, Mueller W, Korshunov A, Hartmann C, von Deimling A (2008) Analysis of the IDH1 codon 132 mutation in brain tumors. Acta Neuropathol 116(6):597-602. https://doi.org/10.1007/s00401-008-0455-2

8. Bandopadhayay P, Ramkissoon LA, Jain P, Bergthold G, Wala J, Zeid R et al (2016) MYB-QKI rearrangements in angiocentric glioma drive tumorigenicity through a tripartite mechanism. Nat Genet 48(3):273-282. https://doi.org/10.1038/ng.3500

9. Banerjee A, Jakacki Rl, Onar-Thomas A, Wu S, Nicolaides T, Young Poussaint T et al (2017) A phase I trial of the MEK inhibitor selumetinib (AZD6244) in pediatric patients with recurrent or refractory low-grade glioma: a Pediatric Brain Tumor Consortium (PBTC) study. Neuro-Oncology 19(8):1135-1144 https://doi.org/10.1093/neuonc/now282

10. Bax DA, Mackay A, Little SE, Carvalho D, Viana-Pereira M, Tamber $\mathrm{N}$ et al (2010) A distinct spectrum of copy number aberrations in pediatric highgrade gliomas. Clin Cancer Res 16(13):3368-3377. https://doi.org/10.1158/ 1078-0432.CCR-10-0438

11. Becker AP, Scapulatempo-Neto C, Carloni AC, Paulino A, Sheren J, Aisner DL et al (2015) KIAA1549: BRAF Gene Fusion and FGFR1 Hotspot Mutations Are Prognostic Factors in Pilocytic Astrocytomas. J Neuropathol Exp Neurol 74(7):743-754. https://doi.org/10.1097/NEN.0000000000000213

12. Bergthold G, Bandopadhayay P, Bi WL, Ramkissoon L, Stiles C, Segal RA et al (2014) Pediatric low-grade gliomas: how modern biology reshapes the clinical field. Biochim Biophys Acta 1845(2):294-307. https:/doi.org/10.1016/j.bbcan.2014.02.004

13. Biernat W, Tohma Y, Yonekawa Y, Kleihues P, Ohgaki H (1997) Alterations of cell cycle regulatory genes in primary (de novo) and secondary glioblastomas. Acta Neuropathol 94(4):303-309

14. Blanchard G, Lafforgue MP, Lion-François L, Kemlin I, Rodriguez D, Castelnau P et al (2016) Systematic MRI in NF1 children under six years of age for the diagnosis of optic pathway gliomas. Study and outcome of a French cohort. Eur J Paediatr Neurol 20(2):275-281. https://doi.org/10.1016/j.ejpn.2015.12.002

15. Bleeker FE, Lamba S, Leenstra S, Troost D, Hulsebos T, Vandertop WP et al (2009) IDH1 mutations at residue p.R132 (IDH1(R132)) occur frequently in high-grade gliomas but not in other solid tumors. Hum Mutat 30(1):7-11. https://doi.org/10.1002/humu.20937

16. Brems H, Beert E, de Ravel T, Legius E (2009) Mechanisms in the pathogenesis of malignant tumours in neurofibromatosis type 1. Lancet Oncol 10(5):508-515. https://doi.org/10.1016/S1470-2045(09)70033-6

17. Broniscer A, Baker SJ, West AN, Fraser MM, Proko E, Kocak M et al (2007) Clinical and molecular characteristics of malignant transformation of lowgrade glioma in children. J Clin Oncol 25(6):682-689

18. Brown NA, Furtado LV, Betz BL, Kiel MJ, Weigelin HC, Lim MS et al (2014) High prevalence of somatic MAP 2K1 mutations in BRAF V600E-negative Langerhans cell histiocytosis. Blood. 124(10):1655-1658. https://doi.org/10. 1182/blood-2014-05-577361

19. Campen CJ, Gutmann DH (2018) Optic Pathway Gliomas in Neurofibromatosis Type 1. J Child Neurol 33(1):73-81. https://doi.org/10. $1177 / 0883073817739509$

20. Capper D, Jones DTW, Sill M, Hovestadt V, Schrimpf D, Sturm D et al (2018) DNA methylation-based classification of central nervous system tumours. Nature. 555(7697):469-474. https://doi.org/10.1038/nature26000

21. Capper D, Preusser M, Habel A, Sahm F, Ackermann U, Schindler G et al (2011) Assessment of BRAF V600E mutation status by immunohistochemistry with a mutation-specific monoclonal antibody. Acta Neuropathol 122(1):11-19. https://doi.org/10.1007/s00401-011-0841-z

22. Capper D, Zentgraf H, Balss J, Hartmann C, von Deimling A (2009) Monoclonal antibody specific for IDH1 R132H mutation. Acta Neuropathol 118(5):599-601. https://doi.org/10.1007/s00401-009-0595-z

23. Chakraborty R, Hampton OA, Shen X, Simko SJ, Shih A, Abhyankar $\mathrm{H}$ et al (2014) Mutually exclusive recurrent somatic mutations in MAP 2K1 and BRAF support a central role for ERK activation in LCH pathogenesis. Blood. 124(19):3007-3015. https://doi.org/10.1182/blood-2014-05-577825

24. Chamberlain MC (2013) Salvage therapy with BRAF inhibitors for recurrent pleomorphic xanthoastrocytoma: a retrospective case series. J Neuro-Oncol 114(2):237-240. https://doi.org/10.1007/s11060-013-1176-5

25. Chan E, Bollen AW, Sirohi D, Van Ziffle J, Grenert JP, Kline CN et al (2017) Angiocentric glioma with MYB-QKI fusion located in the brainstem, rather 
than cerebral cortex. Acta Neuropathol 134(4):671-673. https://doi.org/10. 1007/s00401-017-1759-x

26. Charest A, Wilker EW, McLaughlin ME, Lane K, Gowda R, Coven S et al (2006) ROS fusion tyrosine kinase activates a SH2 domain-containing phosphatase-2/ phosphatidylinositol 3-kinase/mammalian target of rapamycin signaling axis to form glioblastoma in mice. Cancer Res 66(15):7473-7481

27. Chatterjee D, Garg C, Singla N, Radotra BD (2018) Desmoplastic noninfantile astrocytoma/ganglioglioma: rare low-grade tumor with frequent BRAF V600E mutation. Hum Pathol 80:186-191. https://doi.org/10.1016/j. humpath.2018.06.005

28. Chen X, Pan C, Zhang P, Xu C, Sun Y, Yu H et al (2017) BRAF V600E mutation is a significant prognosticator of the tumour regrowth rate in brainstem gangliogliomas. J Clin Neurosci 46:50-57. https://doi.org/10.1016/ j.jocn.2017.09.014

29. Chen Y, Takita J, Choi YL, Kato M, Ohira M, Sanada M et al (2008) Oncogenic mutations of ALK kinase in neuroblastoma. Nature. 455(7215):971-974 https://doi.org/10.1038/nature07399

30. Chen YB, XU J, Skanderup AJ, Dong Y, Brannon AR, Wang L et al (2016) Molecular analysis of aggressive renal cell carcinoma with unclassified histology reveals distinct subsets. Nat Commun 7:13131. https://doi.org/10. 1038/ncomms 13131

31. Chiang J, Harreld JH, Tinkle CL, Moreira DC, Li X, Acharya S et al (2019) A single-center study of the clinicopathologic correlates of gliomas with a MYB or MYBL1 alteration. Acta Neuropathol 138(6):1091-1092. https://doi. org/10.1007/s00401-019-02081-1

32. Cin $H$, Meyer $\mathrm{C}$, Herr R, Janzarik WG, Lambert $\mathrm{S}$, Jones DT, Jacob $\mathrm{K}$ et al (2011) Oncogenic FAM131B-BRAF fusion resulting from 7q34 deletion comprises an alternative mechanism of MAPK pathway activation in pilocytic astrocytoma. Acta Neuropathol 121(6):763-774. https://doi.org/10 1007/s00401-011-0817-z

33. Coccé MC, Mardin BR, Bens S, Stütz AM, Lubieniecki F, Vater I et al (2016) Identification of ZCCHC8 as fusion partner of ROS1 in a case of congenital glioblastoma multiforme with a t(6;12)(q21;q24.3). Genes Chromosom Cancer 55(9):677-687. https://doi.org/10.1002/gcc.22369

34. Collins VP, Jones DT, Giannini C (2015) Pilocytic astrocytoma: pathology, molecular mechanisms and markers. Acta Neuropathol 129(6):775-788. https://doi.org/10.1007/s00401-015-1410-7

35. Dahiya S, Haydon DH, Alvarado D, Gurnett CA, Gutmann DH, Leonard JR (2013) BRAF(V600E) mutation is a negative prognosticator in pediatric ganglioglioma. Acta Neuropathol 125(6):901-910. https://doi.org/10.1007/ s00401-013-1120-y

36. Dai S, Zhou Z, Chen Z, Xu G, Chen Y (2019). Fibroblast Growth Factor Receptors (FGFRs): Structures and Small Molecule Inhibitors. Cells. 8(6). pii: E614. doi: https://doi.org/10.3390/cells8060614

37. D'Angelo F, Ceccarelli M, Tala, Garofano L, Zhang J, Frattini V et al (2019) The molecular landscape of glioma in patients with Neurofibromatosis 1 . Nat Med 25(1):176-187. https://doi.org/10.1038/s41591-018-0263-8

38. D'Aronco L, Rouleau C, Gayden T, Crevier L, Décarie JC, Perreault $S$ et al (2017) Brainstem angiocentric gliomas with MYB-QKI rearrangements. Acta Neuropathol 134(4):667-669. https://doi.org/10.1007/s00401-017-1763-1

39. Das M (2017) Brigatinib effective in ALK-positive non-small-cell lung cancer. Lancet Oncol 18(6):e310. https://doi.org/10.1016/S1470-2045(17)30342-X

40. Davare MA, Henderson JJ, Agarwal A, Wagner JP, Iyer SR, Shah N et al (2018) Rare but Recurrent ROS1 Fusions Resulting From Chromosome 6q22 Microdeletions are Targetable Oncogenes in Glioma. Clin Cancer Res 24(24): 6471-6482. https://doi.org/10.1158/1078-0432.CCR-18-1052

41. De Carli E, Wang X, Puget S (2009) IDH1 and IDH2 mutations in gliomas. N Engl J Med 360(21):2248

42. del Bufalo F, Carai A, Figà-Talamanca L, Pettorini B, Mallucci C, Giangaspero F et al (2014) Response of recurrent BRAFV600E mutated ganglioglioma to Vemurafenib as single agent. J Transl Med 12:356. https://doi.org/10.1186/ s12967-014-0356-1

43. Deng MY, Sill M, Chiang J, Schittenhelm J, Ebinger M, Schuhmann MU et al (2018) Molecularly defined diffuse leptomeningeal glioneuronal tumor (DLGNT) comprises two subgroups with distinct clinical and genetic features. Acta Neuropathol 136(2):239-253. https://doi.org/10.1007/s00401018-1865-4

44. Deshmukh H, Yeh TH, Yu J, Sharma MK, Perry A, Leonard JR et al (2008) High-resolution, dual-platform aCGH analysis reveals frequent HIPK2 amplification and increased expression in pilocytic astrocytomas. Oncogene. 27(34):4745-4751. https://doi.org/10.1038/onc.2008.110
45. Di Stefano AL, Fucci A, Frattini V, Labussiere M, Mokhtari K, Zoppoli P et al (2015) Detection, Characterization, and Inhibition of FGFR-TACC Fusions in IDH Wild-type Glioma. Clin Cancer Res 21(14):3307-3317. https://doi.org/10. 1158/1078-0432.CCR-14-2199

46. Dias-Santagata D, Lam Q, Vernovsky K, Vena N, Lennerz JK, Borger DR, Batchelor TT et al (2011) BRAF V600E mutations are common in pleomorphic xanthoastrocytoma: diagnostic and therapeutic implications. PLoS One 6(3):e17948. https://doi.org/10.1371/journal.pone.0017948

47. Dimitriadis E, Alexiou GA, Tsotsou P, Simeonidi E, Stefanaki K, Patereli A et al (2013) BRAF alterations in pediatric low grade gliomas and mixed neuronalglial tumors. J Neuro-Oncol 113(3):353-358. https://doi.org/10.1007/s11060013-1131-5

48. Diwanji TP, Engelman A, Snider JW, Mohindra P (2017) Epidemiology, diagnosis, and optimal management of glioma in adolescents and young adults. Adolesc Health Med Ther 8:99-113. https://doi.org/10.2147/AHMT.S53391

49. Dodgshun AJ, SantaCruz N, Hwang J, Ramkissoon SH, Malkin H, Bergthold G et al (2016) Disseminated glioneuronal tumors occurring in childhood: treatment outcomes and BRAF alterations including V600E mutation. J Neuro-Oncol 128(2):293-302. https://doi.org/10.1007/s11060-016-2109-x

50. Donson AM, Kleinschmidt-DeMasters BK, Aisner DL, Bemis LT, Birks DK, Levy JM et al (2014) Pediatric brainstem gangliogliomas show BRAF(V600E) mutation in a high percentage of cases. Brain Pathol 24(2):173-183. https:// doi.org/10.1111/bpa.12103

51. Dougherty MJ, Santi M, Brose MS, Ma C, Resnick AC, Sievert AJ et al (2010) Activating mutations in BRAF characterize a spectrum of pediatric lowgrade gliomas. Neuro-Oncology 12(7):621-630. https://doi.org/10.1093/ neuonc/noq007

52. Drilon A, Laetsch TW, Kummar S, DuBois SG, Lassen UN, Demetri GD et al (2018) Efficacy of Larotrectinib in TRK Fusion-Positive Cancers in Adults and Children. N Engl J Med 378(8):731-739. https://doi.org/10.1056/ NEJMoa1714448

53. Drilon A, Siena S, Ou Sl, Patel M, Ahn MJ, Lee J et al (2017) Safety and Antitumor Activity of the Multitargeted Pan-TRK, ROS1, and ALK Inhibitor Entrectinib: Combined Results from Two Phase I Trials (ALKA-372-001 and STARTRK-1). Cancer Discov 7(4):400-409. https://doi.org/10.1158/2159-8290.CD-16-1237

54. Drilon A, Somwar R, Wagner JP, Vellore NA, Eide CA, Zabriskie MS et al (2016) A Novel Crizotinib-Resistant Solvent-Front Mutation Responsive to Cabozantinib Therapy in a Patient with ROS1-Rearranged Lung Cancer. Clin Cancer Res 22(10):2351-2358. https://doi.org/10.1158/1078-0432.CCR-15-2013

55. Erkal HS, Serin M, Cakmak A (1997) Management of optic pathway and chiasmatic-hypothalamic gliomas in children with radiation therapy. Radiother Oncol 45(1):11-15

56. Fangusaro J, Onar-Thomas A, Young Poussaint T, Wu S, Ligon AH, Lindeman N et al (2019) Selumetinib in paediatric patients with BRAF-aberrant or neurofibromatosis type 1-associated recurrent, refractory, or progressive lowgrade glioma: a multicentre, phase 2 trial. Lancet Oncol 20(7):1011-1022. https://doi.org/10.1016/S1470-2045(19)30277-3

57. Faulkner C, Ellis HP, Shaw A, Penman C, Palmer A, Wragg C et al (2015) BRAF Fusion Analysis in Pilocytic Astrocytomas: KIAA1549-BRAF 15-9 Fusions Are More Frequent in the Midline Than Within the Cerebellum. J Neuropathol Exp Neurol 74(9):867-872. https://doi.org/10.1097/NEN. 0000000000000226

58. Fina F, Barets D, Colin C, Bouvier C, Padovani L, Nanni-Metellus I et al (2017) Droplet digital PCR is a powerful technique to demonstrate frequent FGFR1 duplication in dysembryoplastic neuroepithelial tumors. Oncotarget 8(2): 2104-2113. https://doi.org/10.18632/oncotarget.12881

59. Fisher MJ, Loguidice M, Gutmann DH, Listernick R, Ferner RE, Ullrich NJ et al (2012) Visual outcomes in children with neurofibromatosis type 1-associated optic pathway glioma following chemotherapy: a multicenter retrospective analysis. Neuro-Oncology 14(6):790-797. https://doi.org/10.1093/neuonc/nos076

60. Forshew T, Tatevossian RG, Lawson AR, Ma J, Neale G, Ogunkolade BW, et al (2009). Activation of the ERK/MAPK pathway: a signature genetic defect in posterior fossa pilocytic astrocytomas. J Pathol 2009 Jun;218(2):172-181. https://doi.org/10.1002/path.2558.

61. Friedman JM (1999). Epidemiology of neurofibromatosis type 1. Am J Med Genet 1999 89(1):1-6.

62. Furuta A, Takahashi H, lkuta F, Onda K, Takeda N, Tanaka R (1992) Temporal lobe tumor demonstrating ganglioglioma and pleomorphic xanthoastrocytoma components. Case report J Neurosurg 77(1):143-147

63. Furuta T, Miyoshi H, Komaki S, Arakawa F, Morioka M, Ohshima K et al (2018) Clinicopathological and genetic association between epithelioid 
glioblastoma and pleomorphic xanthoastrocytoma. Neuropathology. 38(3): 218-227. https://doi.org/10.1111/neup.12459

64. Garnett MJ, Marais R (2004) Guilty as charged: B-RAF is a human oncogene. Cancer Cell 6(4):313-319

65. Gavine PR, Mooney L, Kilgour E, Thomas AP, Al-Kadhimi K, Beck S et al (2012) AZD4547: an orally bioavailable, potent, and selective inhibitor of the fibroblast growth factor receptor tyrosine kinase family. Cancer Res 72(8): 2045-2056. https://doi.org/10.1158/0008-5472.CAN-11-3034

66. Gessi M, Gielen GH, Dreschmann V, Waha A, Pietsch T (2015) High frequency of $\mathrm{H} 3 \mathrm{~F} 3 \mathrm{~A}$ (K27M) mutations characterizes pediatric and adult high-grade gliomas of the spinal cord. Acta Neuropathol 130(3):435-437. https://doi.org/10.1007/s00401-015-1463-7

67. Gessi M, Moneim YA, Hammes J, Goschzik T, Scholz M, Denkhaus D, Waha A et al (2014 Jun) (2014). FGFR1 mutations in Rosette-forming glioneuronal tumors of the fourth ventricle. J Neuropathol Exp Neurol 73(6):580-584. https://doi.org/10.1097/NEN.0000000000000080

68. Gierke M, Sperveslage J, Schwab D, Beschorner R, Ebinger M, Schuhmann MU, Schittenhelm I (2016) Analysis of IDH1-R132 mutation, BRAF V600 mutation and KIAA1549-BRAF fusion transcript status in central nervous system tumors supports pediatric tumor classification. J Cancer Res Clin Oncol 142(1):89-100. https://doi.org/10.1007/s00432-015-2006-2

69. Goetz R, Mohammadi M (2013) Exploring mechanisms of FGF signalling through the lens of structural biology. Nat Rev Mol Cell Biol 14(3):166-180 https://doi.org/10.1038/nrm3528

70. Gonzales M, Dale S, Susman M, Nolan P, Ng WH, Maixner W et al (2007) Dysembryoplastic neuroepithelial tumor (DNT)-like oligodendrogliomas or Dnts evolving into oligodendrogliomas: two illustrative cases. Neuropathology. 27(4):324-330

71. Grabenbauer GG, Schuchardt U, Buchfelder M, Rödel CM, Gusek G, Marx M et al (2000) Radiation therapy of optico-hypothalamic gliomas (OHG)-radiographic response, vision and late toxicity. Radiother Oncol 54(3):239245

72. Greer A, Foreman NK, Donson A, Davies KD, Kleinschmidt-DeMasters BK (2017) Desmoplastic infantile astrocytoma/ganglioglioma with rare BRAF V600D mutation. Pediatr Blood Cancer 64(6). https://doi.org/10.1002/pbc.26350

73. Guerreiro Stucklin AS, Ryall S, Fukuoka K, Zapotocky M, Lassaletta A, Li C et al (2019) Alterations in ALK/ROS1/NTRK/MET drive a group of infantile hemispheric gliomas. Nat Commun 10(1):4343. https://doi.org/10.1038/ s41467-019-12187-5

74. Haigis KM (2017) KRAS Alleles: The Devil Is in the Detail. Trends Cancer 3(10):686-697. https://doi.org/10.1016/j.trecan.2017.08.006

75. Harel L, Costa B, Fainzilber M (2010) On the death Trk. Dev Neurobiol 70(5): 298-303. https://doi.org/10.1002/dneu.20769

76. Hartmann C, Hentschel B, Tatagiba M, Schramm J, Schnell O, Seidel C et al (2011) Molecular markers in low-grade gliomas: predictive or prognostic? Clin Cancer Res 17(13):4588-4599. https://doi.org/10.1158/1078-0432.CCR-10-3194

77. Hartmann C, Meyer J, Balss J, Capper D, Mueller W, Christians A et al (2009) Type and frequency of IDH1 and IDH2 mutations are related to astrocytic and oligodendroglial differentiation and age: a study of 1,010 diffuse gliomas. Acta Neuropathol 118(4):469-474. https://doi.org/10.1007/s00401009-0561-9

78. Hasselblatt M, Riesmeier B, Lechtape B, Brentrup A, Stummer W, Albert FK et al (2011) BRAF-KIAA1549 fusion transcripts are less frequent in pilocytic astrocytomas diagnosed in adults. Neuropathol Appl Neurobiol 37(7):803806. https://doi.org/10.1111/j.1365-2990.2011.01193.x

79. Hauschild A, Grob JJ, Demidov LV, Jouary T, Gutzmer R, Millward M et al (2012) Dabrafenib in BRAF-mutated metastatic melanoma: a multicentre, open-label, phase 3 randomised controlled trial. Lancet. 380(9839):358-365. https://doi.org/10.1016/S0140-6736(12)60868-X

80. Hawkins C, Walker E, Mohamed N, Zhang C, Jacob K, Shirinian M, et al (2011). BRAF-KIAA1549 fusion predicts better clinical outcome in pediatric low-grade astrocytoma. Clin Cancer Res 2011 Jul 15;17(14):4790-4798. doi: https://doi.org/10.1158/1078-0432.CCR-11-0034.

81. Helgager J, Lidov HG, Mahadevan NR, Kieran MW, Ligon KL, Alexandrescu S (2017) A novel GIT2-BRAF fusion in pilocytic astrocytoma. Diagn Pathol 12(1):82. https://doi.org/10.1186/s13000-017-0669-5

82. Hochart A, Escande F, Rocourt N, Grill J, Koubi-Pick V, Beaujot J et al (2015) Long survival in a child with a mutated K27M-H3.3 pilocytic astrocytoma. Ann Clin Transl Neurol 2(4):439-443. https://doi.org/10.1002/acn3.184

83. Hong DS, Bauer TM, Lee JJ, Dowlati A, Brose MS, Farago AF et al (2019) Larotrectinib in adult patients with solid tumours: a multi-centre, open-label, phase I dose-escalation study. Ann Oncol 30(2):325-331. https://doi.org/10. 1093/annonc/mdy539

84. Horbinski C, Hamilton RL, Nikiforov Y, Pollack IF (2010) Association of molecular alterations, including BRAF, with biology and outcome in pilocytic astrocytomas. Acta Neuropathol 119(5):641-649. https://doi.org/10. 1007/s00401-009-0634-9

85. Horbinski C, Nikiforova MN, Hagenkord JM, Hamilton RL, Pollack IF (2012) Interplay among BRAF, p16, p53, and MIB1 in pediatric low-grade gliomas. Neuro-Oncology 14(6):777-789. https://doi.org/10.1093/neuonc/nos077

86. Houillier C, Wang X, Kaloshi G, Mokhtari K, Guillevin R, Laffaire J et al (2010) $\mathrm{IDH} 1$ or IDH2 mutations predict longer survival and response to temozolomide in low-grade gliomas. Neurology. 75(17):1560-1566. https:// doi.org/10.1212/WNL.0b013e3181f96282

87. Hoyt WF, Baghdassarian SA (1969) Optic glioma of childhood. Natural history and rationale for conservative management. Br J Ophthalmol 53(12):793-798

88. Huse JT, Snuderl M, Jones DT, Brathwaite CD, Altman N, Lavi E et al (2017) Polymorphous low-grade neuroepithelial tumor of the young (PLNTY): an epileptogenic neoplasm with oligodendroglioma-like components, aberrant CD34 expression, and genetic alterations involving the MAP kinase pathway. Acta Neuropathol 133(3):417-429. https://doi.org/10.1007/s00401-016-1639-9

89. Huson SM, Compston DA, Clark P, Harper PS (1989) (1989). A genetic study of von Recklinghausen neurofibromatosis in south east Wales. I. Prevalence, fitness, mutation rate, and effect of parental transmission on severity. J Med Genet 26(11):704-711

90. Jacob K, Albrecht S, Sollier C, Faury D, Sader E, Montpetit A et al (2009) Duplication of 7q34 is specific to juvenile pilocytic astrocytomas and a hallmark of cerebellar and optic pathway tumours. Br J Cancer 101(4):722733. https://doi.org/10.1038/sj.bjc.6605179

91. Jacob K, Quang-Khuong DA, Jones DT, Witt H, Lambert S, Albrecht S et al (2011) Genetic aberrations leading to MAPK pathway activation mediate oncogene-induced senescence in sporadic pilocytic astrocytomas. Clin Cancer Res 17(14):4650-4660. https://doi.org/10.1158/1078-0432.CCR-11-0127

92. Jaeckle KA, Decker PA, Ballman KV, Flynn PJ, Giannini C, Scheithauer BW et al (2011) Transformation of low grade glioma and correlation with outcome: an NCCTG database analysis. J Neuro-Oncol 104(1):253-259. https://doi.org/10.1007/s11060-010-0476-2

93. Jain P, Fierst TM, Han HJ, Smith TE, Vakil A, Storm PB et al (2018) CRAF gene fusions in pediatric low-grade gliomas define a distinct drug response based on dimerization profiles. Oncogene. 9;36(45):6348-6358. https://doi. org/10.1038/onc.2017.276

94. Janzarik WG, Kratz CP, Loges NT, Olbrich H, Klein C, Schäfer T et al (2007) Further evidence for a somatic KRAS mutation in a pilocytic astrocytoma. Neuropediatrics. 38(2):61-63

95. Johnson A, Severson E, Gay L, Vergilio JA, Elvin J, Suh J et al (2017) Comprehensive Genomic Profiling of 282 Pediatric Low- and High-Grade Gliomas Reveals Genomic Drivers, Tumor Mutational Burden, and Hypermutation Signatures. Oncologist. 22(12):1478-1490. https://doi.org/10. 1634/theoncologist.2017-0242

96. Jones DT, Gronych J, Lichter P, Witt O, Pfister SM (2012) MAPK pathway activation in pilocytic astrocytoma. Cell Mol Life Sci 69(11):1799-1811. https://doi.org/10.1007/s00018-011-0898-9

97. Jones DT, Hutter B, Jäger N, Korshunov A, Kool M, Warnatz HJ et al (2013) Recurrent somatic alterations of FGFR1 and NTRK2 in pilocytic astrocytoma. Nat Genet 45(8):927-932. https://doi.org/10.1038/ng.2682

98. Jones DT, Ichimura K, Liu L, Pearson DM, Plant K, Collins VP (2006) Genomic analysis of pilocytic astrocytomas at $0.97 \mathrm{Mb}$ resolution shows an increasing tendency toward chromosomal copy number change with age. J Neuropathol Exp Neurol 65(11):1049-1058

99. Jones DT, Kocialkowski S, Liu L, Pearson DM, Bäcklund LM, Ichimura K et al (2008) Tandem duplication producing a novel oncogenic BRAF fusion gene defines the majority of pilocytic astrocytomas. Cancer Res 68(21):8673-8677. https://doi.org/10.1158/0008-5472.CAN-08-2097

100. Jones DT, Kocialkowski S, Liu L, Pearson DM, Ichimura K, Collins VP (2009) Oncogenic RAF1 rearrangement and a novel BRAF mutation as alternatives to KIAA1549:BRAF fusion in activating the MAPK pathway in pilocytic astrocytoma. Oncogene. 28(20):2119-2123. https://doi.org/10.1038/onc.2009.73

101. Jones DTW, Witt O, Pfister SM (2018) BRAF V600E Status Alone Is Not Sufficient as a Prognostic Biomarker in Pediatric Low-Grade Glioma. J Clin Oncol 36(1):96. https://doi.org/10.1200/JCO.2017.75.8987

102. Joyon N, Tauziède-Espariat A, Alentorn A, Giry M, Castel D, Capelle L et al (2017) K27M mutation in H3F3A in ganglioglioma grade I with spontaneous 
malignant transformation extends the histopathological spectrum of the histone H3 oncogenic pathway. Neuropathol Appl Neurobiol 43(3):271-276. https://doi.org/10.1111/nan.12329

103. Kannan K, Inagaki A, Silber J, Gorovets D, Zhang J, Kastenhuber ER et al (2012) Whole-exome sequencing identifies ATRX mutation as a key molecular determinant in lower-grade glioma. Oncotarget. 3(10):1194-1203

104. Kaplan DR, Miller FD (2000) Neurotrophin signal transduction in the nervous system. Curr Opin Neurobiol 10(3):381-391

105. Karajannis MA, Legault G, Fisher MJ, Milla SS, Cohen KJ, Wisoff JH et al (2014) Phase II study of sorafenib in children with recurrent or progressive low-grade astrocytomas. Neuro-Oncology 16(10):1408-1416. https://doi.org/ 10.1093/neuonc/nou059

106. Kelly LM, Barila G, Liu P, Evdokimova VN, Trivedi S, Panebianco F et al (2014) Identification of the transforming STRN-ALK fusion as a potential therapeutic target in the aggressive forms of thyroid cancer. Proc Natl Acad Sci U S A 111(11):4233-4238. https://doi.org/10.1073/pnas.1321937111

107. Khater F, Langlois S, Cassart P, Roy AM, Lajoie M, Healy J et al (2019) Recurrent somatic BRAF insertion (p.V504_R506dup): a tumor marker and a potential therapeutic target in pilocytic astrocytoma. Oncogene. 38(16): 2994-3002. https://doi.org/10.1038/s41388-018-0623-3

108. Khotskaya YB, Holla VR, Farago AF, Mills Shaw KR, Meric-Bernstam F, Hong DS (2017) Targeting TRK family proteins in cancer. Pharmacol Ther 173:5866. https://doi.org/10.1016/j.pharmthera.2017.02.006

109. Khuong-Quang DA, Buczkowicz P, Rakopoulos P, Liu XY, Fontebasso AM, Bouffet $\mathrm{E}$ et al (2012) K27M mutation in histone H3.3 defines clinically and biologically distinct subgroups of pediatric diffuse intrinsic pontine gliomas. Acta Neuropathol 124(3):439-447. https://doi.org/10.1007/s00401-012-0998-0

110. Kieran MW, Bouffet $E$, Tabori U, Broniscer A, Cohen K, Hansford J, et al (2016). The first study of dabrafenib in pediatric patients with BRAF V600mutant relapsed or refractory low-grade gliomas. Ann Oncol. 27(Suppl 6): LBA19_PR-LBA19_PR.

111. Kim DW, Mehra R, Tan DSW, Felip E, Chow LQM, Camidge DR et al (2016) Activity and safety of ceritinib in patients with ALK-rearranged non-smallcell lung cancer (ASCEND-1): updated results from the multicentre, openlabel, phase 1 trial. Lancet Oncol 17(4):452-463. https:/doi.org/10.1016/ S1470-2045(15)00614-2

112. Kleinschmidt-DeMasters BK, Donson A, Foreman NK, Dorris K (2017) H3 K27M Mutation in Gangliogliomas can be Associated with Poor Prognosis. Brain Pathol 27(6):846-850. https://doi.org/10.1111/bpa.12455

113. Kline CN, Joseph NM, Grenert JP, van Ziffle J, Talevich E, Onodera C et al (2017) Targeted next-generation sequencing of pediatric neuro-oncology patients improves diagnosis, identifies pathogenic germline mutations, and directs targeted therapy. Neuro-Oncology 19(5):699-709. https://doi.org/10. 1093/neuonc/now254

114. Komori T, Arai N (2013) Dysembryoplastic neuroepithelial tumor, a pure glial tumor? Immunohistochemical and morphometric studies. Neuropathology. 33(4):459-468. https://doi.org/10.1111/neup.12033

115. Kondyli M, Larouche V, Saint-Martin C, Ellezam B, Pouliot L, Sinnett D et al (2018) Trametinib for progressive pediatric low-grade gliomas. J NeuroOncol 140(2):435-444. https://doi.org/10.1007/s11060-018-2971-9

116. Korshunov A, Meyer J, Capper D, Christians A, Remke M, Witt H, et al (2009). Combined molecular analysis of BRAF and IDH1 distinguishes pilocytic astrocytoma from diffuse astrocytoma. Acta Neuropathol 2009 Sep;118(3): 401-405. doi: https://doi.org/10.1007/s00401-009-0550-z.

117. Korshunov A, Ryzhova M, Hovestadt V, Bender S, Sturm D, Capper D et al (2015) Integrated analysis of pediatric glioblastoma reveals a subset of biologically favorable tumors with associated molecular prognostic markers. Acta Neuropathol 129(5):669-678. https://doi.org/10.1007/s00401-015-1405-4

118. Krishnatry R, Zhukova N, Guerreiro Stucklin AS, Pole JD, Mistry M, Fried I et al (2016) Clinical and treatment factors determining long-term outcomes for adult survivors of childhood low-grade glioma: A population-based study. Cancer. 122(8):1261-1269. https://doi.org/10.1002/cncr.29907

119. Kuenzle C, Weissert M, Roulet E, Bode H, Schefer S, Huisman T, et al (1994). Follow-up of optic pathway gliomas in children with neurofibromatosis type 1. Neuropediatrics. 1994 Dec;25(6):295-300.

120. Laetsch TW, DuBois SG, Mascarenhas L, Turpin B, Federman N, Albert CM et al (2018) Larotrectinib for paediatric solid tumours harbouring NTRK gene fusions: phase 1 results from a multicentre, open-label, phase 1/2 study. Lancet Oncol 19(5):705-714. https://doi.org/10.1016/S1470-2045(18)30119-0

121. Lassaletta A, Guerreiro Stucklin A, Ramaswamy V, Zapotocky M, McKeown T, Hawkins C et al (2016) Profound clinical and radiological response to BRAF inhibition in a 2-month-old diencephalic child with hypothalamic/chiasmatic glioma. Pediatr Blood Cancer 63(11):2038-2041. https:/doi.org/10.1002/pbc.26086

122. Lassaletta A, Scheinemann K, Zelcer SM, Hukin J, Wilson BA, Jabado N et al (2016) Phase II Weekly Vinblastine for Chemotherapy-Naïve Children With Progressive Low-Grade Glioma: A Canadian Pediatric Brain Tumor Consortium Study. J Clin Oncol 34(29):3537-3543. https://doi.org/10.1200/ JCO.2016.68.1585

123. Lassaletta A, Zapotocky M, Mistry M, Ramaswamy V, Honnorat M, Krishnatry R, Guerreiro Stucklin A et al (2017) Therapeutic and Prognostic Implications of BRAF V600E in Pediatric Low-Grade Gliomas. J Clin Oncol 35(25):29342941. https://doi.org/10.1200/JCO.2016.71.8726

124. Lefkowitz IB, Packer RJ, Sutton LN, Siegel KR, Bruce DA, Evans AE et al (1988) Results of the treatment of children with recurrent gliomas with lomustine and vincristine. Cancer. 61(5):896-902

125. Liggett WH Jr, Sidransky D (1998) Role of the p16 tumor suppressor gene in cancer. J Clin Oncol 16(3):1197-1206

126. Listernick R, Charrow J, Greenwald M, Mets M (1994). Natural history of optic pathway tumors in children with neurofibromatosis type 1: a longitudinal study. J Pediatr 1994 Jul;125(1):63-66.

127. Listernick R, Ferner RE, Liu GT, Gutmann DH (2007) Optic pathway gliomas in neurofibromatosis-1: controversies and recommendations. Ann Neurol 61(3):189-198

128. Liu D, Offin M, Harnicar S, Li BT, Drilon A (2018) Entrectinib: an orally available, selective tyrosine kinase inhibitor for the treatment of NTRK, ROS1, and ALK fusion-positive solid tumors. Ther Clin Risk Manag 14:1247-1252. https://doi.org/10.2147/TCRM.S147381

129. Liu KW, Feng H, Bachoo R, Kazlauskas A, Smith EM, Symes K et al (2011) SHP-2/PTPN11 mediates gliomagenesis driven by PDGFRA and INK4A/ARF aberrations in mice and humans. J Clin Invest 121(3):905-917. https://doi. org/10.1172/JCl43690

130. Liu XY, Gerges N, Korshunov A, Sabha N, Khuong-Quang DA, Fontebasso AM et al (2012 Nov) (2012). Frequent ATRX mutations and loss of expression in adult diffuse astrocytic tumors carrying IDH1/IDH2 and TP53 mutations. Acta Neuropathol 124(5):615-625. https://doi.org/10.1007/ s00401-012-1031-3

131. Louis DN, Ohgaki H, Wiestler OD, Cavenee WK, Burger PC, Jouvet A et al (2007) The 2007 WHO classification of tumours of the central nervous system. Acta Neuropathol 114(2):97-109

132. Louis DN, Perry A, Burger P, Ellison DW, Reifenberger G, von Deimling A et al (2014) International Society Of Neuropathology--Haarlem consensus guidelines for nervous system tumor classification and grading. Brain Pathol 24(5):429-435. https://doi.org/10.1111/bpa.12171

133. Louis DN, Perry A, Reifenberger G, von Deimling A, Figarella-Branger D, Cavenee WK, Ohgaki H et al (2016) The 2016 World Health Organization Classification of Tumors of the Central Nervous System: a summary. Acta Neuropathol 131(6):803-820. https://doi.org/10.1007/s00401-016-1545-1

134. Mackay A, Burford A, Carvalho D, Izquierdo E, Fazal-Salom J, Taylor KR et al (2017) Integrated Molecular Meta-Analysis of 1,000 Pediatric High-Grade and Diffuse Intrinsic Pontine Glioma. Cancer Cell. 32(4):520-537.e5. https://doi. org/10.1016/j.ccell.2017.08.017

135. Marcus KJ, Goumnerova L, Billett AL, Lavally B, Scott RM, Bishop K et al (2005) Stereotactic radiotherapy for localized low-grade gliomas in children: final results of a prospective trial. Int J Radiat Oncol Biol Phys 61(2):374-379

136. Matsumura N, Nobusawa S, Ito J, Kakita A, Suzuki H, Fujii Y et al (2019) Multiplex ligation-dependent probe amplification analysis is useful for detecting a copy number gain of the FGFR1 tyrosine kinase domain in dysembryoplastic neuroepithelial tumors. J Neuro-Oncol 143(1):27-33. https://doi.org/10.1007/s11060-019-03138-7

137. Medeiros LJ, Elenitoba-Johnson KS (2007) Anaplastic Large Cell Lymphoma. Am J Clin Pathol 127(5):707-722

138. Merchant TE, Conklin HM, Wu S, Lustig RH, Xiong X (2009) Late effects of conformal radiation therapy for pediatric patients with low-grade glioma: prospective evaluation of cognitive, endocrine, and hearing deficits. J Clin Oncol 27(22):3691-3697. https://doi.org/10.1200/JCO.2008.21.2738

139. Merchant TE, Kun LE, Wu S, Xiong X, Sanford RA, Boop FA (2009) Phase II trial of conformal radiation therapy for pediatric low-grade glioma. J Clin Oncol 27(22):3598-3604. https://doi.org/10.1200/JCO.2008.20.9494

140. Metellus P, Coulibaly B, Colin C, de Paula AM, Vasiljevic A, Taieb D et al (2010) Absence of IDH mutation identifies a novel radiologic and molecular subtype of WHO grade II gliomas with dismal prognosis. Acta Neuropathol 120(6):719-729. https://doi.org/10.1007/s00401-010-0777-8 
141. Miklja Z, Pasternak A, Stallard S, Nicolaides T, Kline-Nunnally C, Cole B et al (2019) Molecular profiling and targeted therapy in pediatric gliomas: review and consensus recommendations. Neuro Oncol. pii: noz022. https://doi.org/ 10.1093/neuonc/noz022

142. Mistry M, Zhukova N, Merico D, Rakopoulos P, Krishnatry R, Shago M et al (2015) BRAF mutation and CDKN2A deletion define a clinically distinct subgroup of childhood secondary high-grade glioma. J Clin Oncol 33(9): 1015-1022. https://doi.org/10.1200/JCO.2014.58.3922

143. Miyake I, Hakomori Y, Shinohara A, Gamou T, Saito M, Iwamatsu A et al (2002) Activation of anaplastic lymphoma kinase is responsible for hyperphosphorylation of ShcC in neuroblastoma cell lines. Oncogene. 21(38):5823-5834

144. Mossé YP, Lim MS, Voss SD, Wilner K, Ruffner K, Laliberte J et al (2013) Safety and activity of crizotinib for paediatric patients with refractory solid tumours or anaplastic large-cell lymphoma: a Children's Oncology Group phase 1 consortium study. Lancet Oncol 14(6):472-480. https://doi.org/10. 1016/S1470-2045(13)70095-0

145. Nageswara Rao AA, Packer RJ (2014) Advances in the management of lowgrade gliomas. Curr Oncol Rep 16(8):398. https://doi.org/10.1007/s11912014-0398-9

146. Nakano Y, Tomiyama A, Kohno T, Yoshida A, Yamasaki K, Ozawa T et al (2019) Identification of a novel KLC1-ROS1 fusion in a case of pediatric lowgrade localized glioma. Brain Tumor Pathol 36(1):14-19. https://doi.org/10. 1007/s10014-018-0330-3

147. Ng A, Levy ML, Malicki DM, Crawford JR (2019). Unusual high-grade and low-grade glioma in an infant with PPP1CB-ALK gene fusion. BMJ Case Rep. 12(2). pii: e228248. doi: https://doi.org/10.1136/bcr-2018-228248.

148. Nguyen N, Lee SB, Lee YS, Lee KH, Ahn JY (2009) Neuroprotection by NGF and BDNF against neurotoxin-exerted apoptotic death in neural stem cells are mediated through Trk receptors, activating PI3-kinase and MAPK pathways. Neurochem Res 34(5):942-951. https://doi.org/10.1007/s11064008-9848-9

149. Northcott PA, Pfister SM, Jones DT (2015) Next-generation (epi) genetic drivers of childhood brain tumours and the outlook for targeted therapies. Lancet Oncol 16(6):e293-e302. https://doi.org/10.1016/S14702045(14)71206-9

150. Ohgaki H, Kleihues P (2009) Genetic alterations and signaling pathways in the evolution of gliomas. Cancer Sci 100(12):2235-2241. https://doi.org/10. 1111/j.1349-7006.2009.01308.x

151. Okita Y, Narita Y, Miyakita Y, Ohno M, Matsushita Y, Fukushima S et al (2012) $\mathrm{IDH} 1 / 2$ mutation is a prognostic marker for survival and predicts response to chemotherapy for grade II gliomas concomitantly treated with radiation therapy. Int J Oncol 41(4):1325-1336. https://doi.org/10.3892/ijo.2012.1564

152. Olsen TK, Panagopoulos I, Meling TR, Micci F, Gorunova L, Thorsen J et al (2015) Fusion genes with ALK as recurrent partner in ependymoma-like gliomas: a new brain tumor entity? Neuro-Oncology 17(10):1365-1373. https://doi.org/10.1093/neuonc/nov039

153. Orillac C, Thomas C, Dastagirzada Y, Hidalgo ET, Golfinos JG, Zagzag D et al (2016) Pilocytic astrocytoma and glioneuronal tumor with histone H3 K27M mutation. Acta Neuropathol Commun 4(1):84. https://doi.org/10.1186/ s40478-016-0361-0

154. Ostrom QT, de Blank PM, Kruchko C, Petersen CM, Liao P, Finlay JL et al (2015) Alex's Lemonade Stand Foundation Infant and Childhood Primary Brain and Central Nervous System Tumors Diagnosed in the United States in 2007-2011. Neuro Oncol Suppl 10:x1-x36. https://doi.org/10.1093/ neuonc/nou327

155. Ostrom QT, Gittleman H, Truitt G, Boscia A, Kruchko C, Barnholtz-Sloan JS (2018). CBTRUS Statistical Report: Primary Brain and Other Central Nervous System Tumors Diagnosed in the United States in 2011-2015. Neuro Oncol. Suppl_4:iv1-iv86. doi: https://doi.org/10.1093/neuonc/noy131.

156. Ozkaya N, Rosenblum MK, Durham BH, Pichardo JD, Abdel-Wahab O, Hameed MR et al (2018) The histopathology of Erdheim-Chester disease: a comprehensive review of a molecularly characterized cohort. Mod Pathol 31(4):581-597. https://doi.org/10.1038/modpathol.2017.160

157. Packer RJ, Lange B, Ater J, Nicholson HS, Allen J, Walker R et al (1993) Carboplatin and vincristine for recurrent and newly diagnosed low-grade gliomas of childhood. J Clin Oncol 11(5):850-856

158. Pagès M, Beccaria K, Boddaert N, Saffroy R, Besnard A, Castel D et al (2018) Co-occurrence of histone H3 K27M and BRAF V600E mutations in paediatric midline grade I ganglioglioma. Brain Pathol 28(1):103-111. https://doi.org/ 10.1111/bpa.12473
159. Parsa CF, Hoyt CS, Lesser RL, Weinstein JM, Strother CM, Muci-Mendoza R et al (2001) Spontaneous regression of optic gliomas: thirteen cases documented by serial neuroimaging. Arch Ophthalmol 119(4):516-529

160. Pattabiraman DR, Gonda TJ (2013) Role and potential for therapeutic targeting of MYB in leukemia. Leukemia. 27(2):269-277. https://doi.org/10. 1038/leu.2012.225

161. Paugh BS, Broniscer A, Qu C, Miller CP, Zhang J, Tatevossian RG et al (2011) Genome-wide analyses identify recurrent amplifications of receptor tyrosine kinases and cell-cycle regulatory genes in diffuse intrinsic pontine glioma. J Clin Oncol 29(30):3999-4006. https://doi.org/10.1200/JCO.2011.35.5677

162. Paugh BS, Qu C, Jones C, Liu Z, Adamowicz-Brice M, Zhang J et al (2010) Integrated molecular genetic profiling of pediatric high-grade gliomas reveals key differences with the adult disease. J Clin Oncol 28(18):30613068. https://doi.org/10.1200/JCO.2009.26.7252

163. Pekmezci M, Stevers M, Phillips JJ, Van Ziffle J, Bastian BC, Tsankova NM et al (2018) Multinodular and vacuolating neuronal tumor of the cerebrum is a clonal neoplasm defined by genetic alterations that activate the MAP kinase signaling pathway. Acta Neuropathol 135(3):485-488. https://doi.org/10. 1007/s00401-018-1820-4

164. Pekmezci M, Villanueva-Meyer JE, Goode B, Van Ziffle J, Onodera C, Grenert JP et al (2018) The genetic landscape of ganglioglioma. Acta Neuropathol Commun 6(1):47. https://doi.org/10.1186/s40478-018-0551-z

165. Perry A, Anderl K, Borell TJ, Kimmel DW, Wang CH, O'Fallon JR et al (1999) Detection of p16, RB, CDK4, and p53 gene deletion and amplification by fluorescence in situ hybridization in 96 gliomas. Am J Clin Pathol 112(6): 801-809

166. Perry A, Wesseling P (2016) Histologic classification of gliomas. Handb Clin Neurol 134:71-95. https://doi.org/10.1016/B978-0-12-802997-8.00005-0

167. Pfister S, Janzarik WG, Remke M, Ernst A, Werft W, Becker N et al (2008) BRAF gene duplication constitutes a mechanism of MAPK pathway activation in low-grade astrocytomas. J Clin Invest 118(5):1739-1749. https:// doi.org/10.1172/JCl33656

168. Pollack IF (1994) Brain tumors in children. N Engl J Med 331(22):1500-1507

169. Pollack IF, Hamilton RL, Sobol RW, Nikiforova MN, Lyons-Weiler MA, LaFramboise WA et al (2011) IDH1 mutations are common in malignant gliomas arising in adolescents: a report from the Children's Oncology Group. Childs Nerv Syst 27(1):87-94. https://doi.org/10.1007/s00381-0101264-1

170. Purkait S, Jha P, Sharma MC, Suri V, Sharma M, Kale SS et al (2013) CDKN2A deletion in pediatric versus adult glioblastomas and predictive value of p16 immunohistochemistry. Neuropathology. 33(4):405-412. https://doi.org/10. 1111/neup.12014

171. Qaddoumi I, Orisme W, Wen J, Santiago T, Gupta K, Dalton JD, et al (2016). Genetic alterations in uncommon low-grade neuroepithelial tumors: BRAF, FGFR1, and MYB mutations occur at high frequency and align with morphology. Acta Neuropathol 2016 Jun;131(6):833-845. doi: https://doi.org/ 10.1007/s00401-016-1539-z.

172. Quan PL, Sauzade M, Brouzes E (2018) dPCR: A Technology Review. Sensors (Basel). 18(4). pii: E1271. https://doi.org/10.3390/s18041271

173. Raabe EH, Lim KS, Kim JM, Meeker A, Mao XG, Nikkhah G et al (2011) BRAF activation induces transformation and then senescence in human neural stem cells: a pilocytic astrocytoma model. Clin Cancer Res 17(11):3590-3599. https://doi.org/10.1158/1078-0432.CCR-10-3349

174. Ramkissoon LA, Horowitz PM, Craig JM, Ramkissoon SH, Rich BE, Schumacher SE et al (2013) Genomic analysis of diffuse pediatric low-grade gliomas identifies recurrent oncogenic truncating rearrangements in the transcription factor MYBL1. Proc Natl Acad Sci U S A 110(20):8188-8193. https://doi.org/10.1073/pnas.1300252110

175. Ramkissoon SH, Bandopadhayay P, Hwang J, Ramkissoon LA, Greenwald NF, Schumacher SE et al (2017) Clinical targeted exome-based sequencing in combination with genome-wide copy number profiling: precision medicine analysis of 203 pediatric brain tumors. Neuro-Oncology 19(7):986-996. https://doi.org/10.1093/neuonc/now294

176. Rand V, Huang J, Stockwell T, Ferriera S, Buzko O, Levy S et al (2005) Sequence survey of receptor tyrosine kinases reveals mutations in glioblastomas. Proc Natl Acad Sci U S A 102(40):14344-14349

177. Rasmussen SA, Friedman JM (2000) NF1 gene and neurofibromatosis 1. Am J Epidemiol 151(1):33-40

178. Reinhardt A, Stichel D, Schrimpf D, Sahm F, Korshunov A, Reuss DE et al (2018) Anaplastic astrocytoma with piloid features, a novel molecular class of IDH wildtype glioma with recurrent MAPK pathway, CDKN2A/B and ATRX 
alterations. Acta Neuropathol 136(2):273-291. https://doi.org/10.1007/ s00401-018-1837-8

179. Rivera B, Gayden T, Carrot-Zhang J, Nadaf J, Boshari T, Faury D et al (2016) Germline and somatic FGFR1 abnormalities in dysembryoplastic neuroepithelial tumors. Acta Neuropathol 131(6):847-863. https://doi.org/10. 1007/s00401-016-1549-x

180. Roccograndi L, Binder ZA, Zhang L, Aceto N, Zhang Z, Bentires-Alj M, et al (2017). SHP2 regulates proliferation and tumorigenicity of glioma stem cells. J Neuro-Oncol 2017 Dec;135(3):487-496. doi: https://doi.org/10.1007/s11060017-2610-x

181. Rodriguez FJ, Schniederjan MJ, Nicolaides T, Tihan T, Burger PC, Perry A (2015) High rate of concurrent BRAF-KIAA1549 gene fusion and 1p deletion in disseminated oligodendroglioma-like leptomeningeal neoplasms (DOLN). Acta Neuropathol 129(4):609-610. https://doi.org/10. 1007/s00401-015-1400-9

182. Romano AA, Allanson JE, Dahlgren J, Gelb BD, Hall B, Pierpont ME et al (2010) Noonan syndrome: clinical features, diagnosis, and management guidelines. Pediatrics. 126(4):746-759. https://doi.org/10.1542/peds.20093207

183. Rosenstock JG, Evans AE, Schut L (1976) Response to vincristine of recurrent brain tumors in children. J Neurosurg 45(2):135-140

184. Ruas M, Peters G (1998) The p16INK4a/CDKN2A tumor suppressor and its relatives. Biochim Biophys Acta 1378(2):F115-F177

185. Rush S, Foreman N, Liu A (2013) Brainstem ganglioglioma successfully treated with vemurafenib. J Clin Oncol 31(10):e159-e160. https://doi.org/10. 1200/JCO.2012.44.1568

186. Ryall S, Arnoldo A, Krishnatry R, Mistry M, Khor K, Sheth J, Ling C et al (2017) Multiplex Detection of Pediatric Low-Grade Glioma Signature Fusion Transcripts and Duplications Using the NanoString nCounter System. J Neuropathol Exp Neurol 76(7):562-570. https://doi.org/10.1093/jnen/nlx042

187. Ryall S, Krishnatry R, Arnoldo A, Buczkowicz P, Mistry M, Siddaway R et al (2016) Targeted detection of genetic alterations reveal the prognostic impact of H3K27M and MAPK pathway aberrations in paediatric thalamic glioma. Acta Neuropathol Commun 4(1):93. https://doi.org/10.1186/s40478016-0353-0

188. Sanson M, Marie Y, Paris S, Idbaih A, Laffaire J, Ducray F et al (2009) Isocitrate dehydrogenase 1 codon 132 mutation is an important prognostic biomarker in gliomas. J Clin Oncol 27(25):4150-4154. https://doi.org/10. 1200/JCO.2009.21.9832

189. Saran FH, Baumert BG, Khoo VS, Adams EJ, Garré ML, Warrington AP et al (2002) Stereotactically guided conformal radiotherapy for progressive lowgrade gliomas of childhood. Int J Radiat Oncol Biol Phys 53(1):43-51

190. Schiffman JD, Hodgson JG, VandenBerg SR, Flaherty P, Polley MY, Yu M et a (2010) Oncogenic BRAF mutation with CDKN2A inactivation is characteristic of a subset of pediatric malignant astrocytomas. Cancer Res 70(2):512-519. https://doi.org/10.1158/0008-5472.CAN-09-1851

191. Schindler G, Capper D, Meyer J, Janzarik W, Omran H, Herold-Mende C et al (2011) Analysis of BRAF V600E mutation in 1,320 nervous system tumors reveals high mutation frequencies in pleomorphic xanthoastrocytoma, ganglioglioma and extra-cerebellar pilocytic astrocytoma. Acta Neuropathol 121(3):397-405. https://doi.org/10.1007/s00401-011-0802-6

192. Schramm A, Schulte JH, Astrahantseff K, Apostolov O, VV L, Sieverts $H$ et al (2005) Biological effects of TrkA and TrkB receptor signaling in neuroblastoma. Cancer Lett 228(1-2):143-153

193. Schwartzentruber J, Korshunov A, Liu XY, Jones DT, Pfaff E, Jacob K et al (2012) Driver mutations in histone H3.3 and chromatin remodelling genes in paediatric glioblastoma. Nature. 482(7384):226-231. https://doi.org/10. 1038/nature10833

194. Scott LJ (2019) Larotrectinib: First Global Approval. Drugs. 79(2):201-206. https://doi.org/10.1007/s40265-018-1044-x

195. Sellmer L, Farschtschi S, Marangoni M, Heran MK, Birch P, Wenzel R et al (2017) Non-optic glioma in adults and children with neurofibromatosis 1. Orphanet J Rare Dis 12(1):34. https://doi.org/10.1186/s13023-017-0588-2

196. Seminog OO, Goldacre MJ (2013 Jan 15) (2013). Risk of benign tumours of nervous system, and of malignant neoplasms, in people with neurofibromatosis: population-based record-linkage study. Br J Cancer 108(1):193-198. https://doi.org/10.1038/bjc.2012.535

197. Sharif S, Ferner R, Birch JM, Gillespie JE, Gattamaneni HR, Baser ME et al (2006) Second primary tumors in neurofibromatosis 1 patients treated for optic glioma: substantial risks after radiotherapy. J Clin Oncol 24(16): 2570-2575
198. Shaw AT, Ou SH, Bang YJ, Camidge DR, Solomon BJ, Salgia R et al (2014) Crizotinib in ROS1-rearranged non-small-cell lung cancer. N Engl J Med 371(21):1963-1971. https://doi.org/10.1056/NEJMoa1406766

199. Sievert AJ, Fisher MJ (2009) Pediatric low-grade gliomas. J Child Neurol 24(11):1397-1408. https://doi.org/10.1177/0883073809342005

200. Sievert AJ, Jackson EM, Gai X, Hakonarson H, Judkins AR, Resnick AC et al (2009) Duplication of 7q34 in pediatric low-grade astrocytomas detected by high-density single-nucleotide polymorphism-based genotype arrays results in a novel BRAF fusion gene. Brain Pathol 19(3):449-458. https://doi.org/10. 1111/j.1750-3639.2008.00225.x

201. Sievert AJ, Lang SS, Boucher KL, Madsen PJ, Slaunwhite E, Choudhari N et al (2013) Paradoxical activation and RAF inhibitor resistance of BRAF protein kinase fusions characterizing pediatric astrocytomas. Proc Natl Acad Sci U S A 110(15):5957-5962. https://doi.org/10.1073/pnas.1219232110

202. Singh D, Chan JM, Zoppoli P, Niola F, Sullivan R, Castano A et al (2012) Transforming fusions of FGFR and TACC genes in human glioblastoma. Science. 337(6099):1231-1235. https://doi.org/10.1126/science.1220834

203. Skrypek M, Foreman N, Guillaume D, Moertel C (2014) Pilomyxoid astrocytoma treated successfully with vemurafenib. Pediatr Blood Cancer 61(11):2099-2100. https://doi.org/10.1002/pbc.25084

204. Solomon DA, Korshunov A, Sill M, Jones DTW, Kool M, Pfister SM et al (2018) Myxoid glioneuronal tumor of the septum pellucidum and lateral ventricle is defined by a recurrent PDGFRA p.K385 mutation and DNT-like methylation profile. Acta Neuropathol 136(2):339-343. https://doi.org/10. 1007/s00401-018-1883-2

205. Solomon DA, Wood MD, Tihan T, Bollen AW, Gupta N, Phillips JJ et al (2016) Diffuse Midline Gliomas with Histone H3-K27M Mutation: A Series of 47 Cases Assessing the Spectrum of Morphologic Variation and Associated Genetic Alterations. Brain Pathol 26(5):569-580. https://doi.org/10.1111/bpa. 12336

206. Sosman JA, Kim KB, Schuchter L, Gonzalez R, Pavlick AC, Weber JS et al (2012) Survival in BRAF V600-mutant advanced melanoma treated with vemurafenib. N Engl J Med 366(8):707-714. https://doi.org/10.1056/ NEJMoa1112302

207. Sturm D, Witt H, Hovestadt V, Khuong-Quang DA, Jones DT, Konermann C et al (2012) Hotspot mutations in H3F3A and IDH1 define distinct epigenetic and biological subgroups of glioblastoma. Cancer Cell 22(4):425-437. https:// doi.org/10.1016/j.ccr.2012.08.024

208. Sugita Y, Irie K, Ohshima K, Hitotsumatsu T, Sato O, Arimura K (2009) Pleomorphic xanthoastrocytoma as a component of a temporal lobe cystic ganglioglioma: a case report. Brain Tumor Pathol 26(1):31-36. https://doi. org/10.1007/s10014-009-0244-1

209. Surrey LF, MacFarland SP, Chang F, Cao K, Rathi KS, Akgumus GT et al (2019) Clinical utility of custom-designed NGS panel testing in pediatric tumors. Genome Med 11(1):32. https://doi.org/10.1186/s13073-019-0644-8

210. Tanaka S, Nakada M, Nobusawa S, Suzuki SO, Sabit H, Miyashita K et al (2014) Epithelioid glioblastoma arising from pleomorphic xanthoastrocytoma with the BRAF V600E mutation. Brain Tumor Pathol 31(3):172-176. https://doi.org/10.1007/s10014-014-0192-2

211. Tatevossian RG, Lawson AR, Forshew T, Hindley GF, Ellison DW, Sheer D (2010) MAPK pathway activation and the origins of pediatric low-grade astrocytomas. J Cell Physiol 222(3):509-514. https://doi.org/10.1002/jcp. 21978

212. Tatevossian RG, Tang B, Dalton J, Forshew T, Lawson AR, Ma J et al (2010) MYB upregulation and genetic aberrations in a subset of pediatric lowgrade gliomas. Acta Neuropathol 120(6):731-743. https://doi.org/10.1007/ s00401-010-0763-1

213. Thiele CJ, Li Z, McKee AE (2009) On Trk--the TrkB signal transduction pathway is an increasingly important target in cancer biology. Clin Cancer Res 15(19):5962-5967. https://doi.org/10.1158/1078-0432.CCR-08-0651

214. Tian Y, Rich BE, Vena N, Craig JM, Macconaill LE, Rajaram V et al (2011) Detection of KIAA1549-BRAF fusion transcripts in formalin-fixed paraffinembedded pediatric low-grade gliomas. J Mol Diagn 13(6):669-677. https:// doi.org/10.1016/j.jmoldx.2011.07.002

215. Torre M, Jessop N, Hornick JL, Alexandrescu S (2018) Expanding the spectrum of pediatric NTRK-rearranged fibroblastic tumors to the central nervous system: A case report with RBPMS-NTRK3 fusion. Neuropathology 38(6):624-630. https://doi.org/10.1111/neup.12513

216. Turner N, Grose R (2010) Fibroblast growth factor signalling: from development to cancer. Nat Rev Cancer 10(2):116-129. https://doi.org/10. $1038 /$ nrc2780 
217. Tutuka CSA, Andrews MC, Mariadason JM, loannidis P, Hudson C, Cebon J et al (2017) PLX8394, a new generation BRAF inhibitor, selectively inhibits BRAF in colonic adenocarcinoma cells and prevents paradoxical MAPK pathway activation. Mol Cancer 16(1):112. https://doi.org/10.1186/s12943017-0684-x

218. Uusitalo E, Rantanen M, Kallionpää RA, Pöyhönen M, Leppävirta J, YläOutinen $\mathrm{H}$ et al (2016) Distinctive Cancer Associations in Patients With Neurofibromatosis Type 1. J Clin Oncol 34(17):1978-1986. https://doi.org/10. 1200/JCO.2015.65.3576

219. Vaishnavi A, Le AT DRC (2015) TRKing down an old oncogene in a new era of targeted therapy. Cancer Discov 5(1):25-34. https://doi.org/10.1158/21598290.CD-14-0765

220. Vanden Borre P, Schrock AB, Anderson PM, Morris JC, Heilmann AM, Holmes $O$ et al (2017) Pediatric, Adolescent, and Young Adult Thyroid Carcinoma Harbors Frequent and Diverse Targetable Genomic Alterations, Including Kinase Fusions. Oncologist. 22(3):255-263. https://doi.org/10.1634/ theoncologist.2016-0279

221. Venneti S, Santi M, Felicella MM, Yarilin D, Phillips JJ, Sullivan LM et al (2014) A sensitive and specific histopathologic prognostic marker for H3F3A K27M mutant pediatric glioblastomas. Acta Neuropathol 128(5):743-753. https:// doi.org/10.1007/s00401-014-1338-3

222. Wan PT, Garnett MJ, Roe SM, Lee S, Niculescu-Duvaz D, Good VM, Jones CM et al (2004) Mechanism of activation of the RAF-ERK signaling pathway by oncogenic mutations of B-RAF. Cell. 116(6):855-867

223. Wefers AK, Stichel D, Schrimpf D, Coras R, Pages M, Tauziède-Espariat A et al (2020) Isomorphic diffuse glioma is a morphologically and molecularly distinct tumour entity with recurrent gene fusions of MYBL1 or MYB and a benign disease course. Acta Neuropathol 139(1):193-209. https://doi.org/10. 1007/s00401-019-02078-w

224. Wen PY, Drappatz J, de Groot J, Prados MD, Reardon DA, Schiff D et al (2018) Phase II study of cabozantinib in patients with progressive glioblastoma: subset analysis of patients naive to antiangiogenic therapy. Neuro-Oncology 20(2):249-258. https://doi.org/10.1093/neuonc/nox154

225. Wisoff JH, Sanford RA, Heier LA, Sposto R, Burger PC, Yates AJ et al (2011) Primary neurosurgery for pediatric low-grade gliomas: a prospective multiinstitutional study from the Children's Oncology Group. Neurosurgery. 68(6): 1548-1554. https://doi.org/10.1227/NEU.0b013e318214a66e

226. Wu G, Broniscer A, McEachron TA, Lu C, Paugh BS, Becksfort J et al (2012) Somatic histone $\mathrm{H} 3$ alterations in pediatric diffuse intrinsic pontine gliomas and non-brainstem glioblastomas. Nat Genet 44(3):251-253. https://doi.org/ 10.1038/ng.1102

227. Wu G, Diaz AK, Paugh BS, Rankin SL, Ju B, Li Y et al (2012) The genomic landscape of diffuse intrinsic pontine glioma and pediatric non-brainstem high-grade glioma. Nat Genet 46(5):444-450. https://doi.org/10.1038/ng.2938

228. Yan H, Parsons DW, Jin G, McLendon R, Rasheed BA, Yuan W et al (2009) IDH1 and IDH2 mutations in gliomas. N Engl J Med 360(8):765-773. https:// doi.org/10.1056/NEJMoa0808710

229. Zhang J, Wu G, Miller CP, Tatevossian RG, Dalton JD, Tang B et al (2013 Jun) (2013). Whole-genome sequencing identifies genetic alterations in pediatric low-grade gliomas. Nat Genet 45(6):602-612. https://doi.org/10.1038/ng.2611

230. Zhou Y, Ness SA (2011) Myb proteins: angels and demons in normal and transformed cells. Front Biosci (Landmark Ed) 16:1109-1131

\section{Publisher's Note}

Springer Nature remains neutral with regard to jurisdictional claims in published maps and institutional affiliations.

Ready to submit your research? Choose BMC and benefit from:

- fast, convenient online submission

- thorough peer review by experienced researchers in your field

- rapid publication on acceptance

- support for research data, including large and complex data types

- gold Open Access which fosters wider collaboration and increased citations

- maximum visibility for your research: over $100 \mathrm{M}$ website views per year

At BMC, research is always in progress.

Learn more biomedcentral.com/submissions 